Research Article

\title{
Bioavailability and Solubility of Heavy Metals and Trace Elements during Composting of Cow Manure and Tree Litter
}

\author{
Kelvin Reyes Pinto $\left(\mathbb{D},{ }^{1,2}\right.$ Víctor Meza-Contreras ${ }^{(D)},{ }^{1}$ Julio César Alegre-Orihuela $\left(\mathbb{D},{ }^{1}\right.$ \\ and Warren Réategui-Romero (D) $^{3}$ \\ ${ }^{1}$ Universidad Nacional Agraria La Molina, Av. La Molina s/n, Lima 12, Lima, Peru \\ ${ }^{2}$ Domus Consultoria Ambiental S.A.C, Jr. Combate de Iquique No. 716, Lima 33, Lima, Peru \\ ${ }^{3}$ Universidad Nacional de Ingeniería, Facultad de Ingeniería Química y Textil (FIQT), Av. Túpac Amaru No. 210, Lima 25, \\ Lima, Peru
}

Correspondence should be addressed to Kelvin Reyes Pinto; kreyes@domusperu.com

Received 16 January 2020; Revised 26 November 2020; Accepted 3 December 2020; Published 30 December 2020

Academic Editor: Rafael Clemente

Copyright (c) 2020 Kelvin Reyes Pinto et al. This is an open access article distributed under the Creative Commons Attribution License, which permits unrestricted use, distribution, and reproduction in any medium, provided the original work is properly cited.

\begin{abstract}
Objectives. To characterize the total content of heavy metals (Cd, $\mathrm{Cr}, \mathrm{Cu}, \mathrm{Hg}, \mathrm{Mo}, \mathrm{Ni}, \mathrm{Pb}$, and $\mathrm{Zn}$ ) and trace elements (As and $\mathrm{Se}$ ) of interest, their bioavailability and solubility during the composting of cow manure and tree litter in piles inoculated with beneficial microorganism (IBM), or not inoculated (NBM), on the university campus of the Universidad Nacional Agraria La Molina (UNALM). Methods. The investigation evaluated composting in six piles, three IBM piles and three NBM piles, for 120 days. Every 30 days, a composite sample was taken from each pile. The raw materials used were cattle manure and tree litter. The variables analyzed were the total concentrations (content) of metals and trace elements of interest, extracted with diethylenetriaminepentaacetic acid/pentatetic acid (DTPA) (for the bioavailability study) and extracted with deionized water (for the solubility study). Results. The average values $(n=3)$ of the total content $\left(\mathrm{mg} \cdot \mathrm{kg}^{-1}\right)$ on day $120 \mathrm{in} \mathrm{IBM}$ were in the following order: $\mathrm{Zn}(404.33)>\mathrm{Cu}(86.33)>\mathrm{Pb}(71.2)>\mathrm{Cr}(34.33)>\mathrm{As}(28.0)>\mathrm{Ni}(13.83)>\mathrm{Mo}(2.86)>\mathrm{Se}(1.38)>\mathrm{Cd}(1.32)>\mathrm{Hg}(0.39)$ and in NBM: $\mathrm{Zn}(466.0)>\mathrm{Cu}(112.23)>\mathrm{Pb}(73.23)>\mathrm{Cr}(35.33)>\mathrm{As}(29.67)>\mathrm{Ni}(14.37)>\mathrm{Mo}(3.23)>\mathrm{Se}(1.55)>\mathrm{Cd}(1.38)>\mathrm{Hg}(0.38)$. The values complied with the Austrian Compost Standard for Landscaping and Land Rehabilitation and the Peruvian Standard for Nonorganic Agriculture. Significant differences were observed in some elements $(p<0.05)$ between 0 and 120 days in both types of pile (IBM and NBM). Conclusions. For nonorganic agriculture in Peru, urban compost is recommended, whereby raw organic materials are inoculated with beneficial microorganisms during the composting process to reduce the bioavailability of $\mathrm{Cu}$ and $\mathrm{Zn}$, as these elements showed less bioavailability than noninoculated piles. The composting process for both piles (IBM and NBM) reduced the solubility in $\mathrm{Cu}, \mathrm{Pb}$, and $\mathrm{Zn}$.
\end{abstract}

\section{Introduction}

The heavy metals present in plants and their bioavailability are a concern because of the multiple adverse effects on human health that these chemical elements have [1-3] as well as carcinogenic and neurological effects $[4,5]$. The heavy metals present in plants in urban areas come mainly from air pollution generated by burning fuel and emissions from the manufacturing industry [6-9]. Other forms of contamination include irrigation water [10], inorganic fertilizer [11], and organic fertilization with compost [12, 13].
The world's population has migrated mainly from rural areas to urban areas [14], thus increasing the demand for food in the latter. Due to this need, the practice of urban agriculture is recommended [15] to produce plant food. However, research has shown that there is contamination in crops in these areas $[8,16]$.

Compost is an amendment that is used in urban agriculture [15], especially in poorer areas, because it is a lowcost technique for recycling organic matter and is easy to handle [17]. Compost has the virtue of being a soil improver and also provides nutrients to plants $[18,19]$. However, due 
to the raw materials used, it can contain significant contents of heavy metals [18, 20-24]. It is known that green spaces with arboreal vegetation in an urban environment retain heavy metals in the foliage due to the precipitation of atmospheric dust produced mainly by the use of fossil fuels by vehicular traffic [7, 25-31]. It is also known that cattle manure contains significant amounts of some heavy metals [32-36] which is due to the fact that cattle feed has nutrients fortified with these elements and that, in some cases, the quantities supplied are greater than the absorption in the digestive process, whereby these are excreted [34, 35].

Humic and fulvic acids are generated during the composting process, which can influence the mobility of metals and trace elements, thus reducing their bioavailability for plants $[24,37-39]$. The total content of heavy metals and trace elements analyzed during the composting process is not an adequate indicator of their bioavailability $[18,21]$. Therefore, it is important to use an extractant such as pentatetic acid (DTPA) to determine their bioavailability $[21,40]$ or deionized water to determine their solubility [24, 37, 41, 42].

Inoculation with beneficial microorganisms (BMs) is a bioremediation technique used in areas with soil contaminated by heavy metals whereby their bioavailability and solubility are reduced $[43,44]$. Due to the presence of these polluting elements in the raw materials used in composting in urban areas, it could be a useful technique to reduce their availability in the compost produced [45]. It is known that $\mathrm{BM}$ can improve the composting process, reducing the required time and increasing the contents of macroelements such as $\mathrm{N}, \mathrm{P}$, and $\mathrm{K}[46,47]$. One of the metabolic properties of these organisms is that they can promote changes in the speciation of metals towards less polluting forms, and they can adsorb them on their own structures [48]. BMs are considered to be microbial consortia made up of yeasts and bacteria that increase the metabolism of the degradation of the raw organic components of the composting piles, especially the lignocellulose elements, towards more assimilable intermediates in the food chain of the microbiological ecosystem [49].

The objective of this investigation was the characterization of the total content of heavy metals and trace elements of interest, as well as their bioavailability and solubility, during the composting of cow manure and tree litter in piles inoculated, or not inoculated, with beneficial microorganisms on the university campus of the Universidad Nacional Agraria La Molina (UNALM).

\section{Materials and Methods}

2.1. Location. The university campus of UNALM is located in the district of La Molina, in the province of Lima, department of Lima, in Peru. It is at an altitude of 246 meters above sea level, and the average temperature is between 15 and $26^{\circ} \mathrm{C}$ (Figure 1).

\subsection{Materials}

2.2.1. Raw Materials for the Investigation Stages. The research had two distinct stages. The characterization stage analyzed the total contents of heavy metals, $\mathrm{Cd}, \mathrm{Cr}, \mathrm{Cu}, \mathrm{Hg}$, $\mathrm{Mo}, \mathrm{Ni}, \mathrm{Pb}$, and $\mathrm{Zn}$, and of trace elements, As and $\mathrm{Se}$, of interest (HM\&TE) in the products from co-composting cow manure (COW-M) and grass clipping (GRASS-C) and from composting of tree litter (TREE-L), two types of compost that are produced on the UNALM campus. The evaluation stage investigated the total contents, bioavailability, and solubility of the HM\&TE during the composting of COW-M and TREE-L in piles inoculated with beneficial microorganisms (IBMs) and in piles which were not inoculated with microorganisms (NBM). The piles were of pyramidal form, $0.8 \mathrm{~m}$ high with a $3 \mathrm{~m}$ base for the co-composting (manure and vegetal material) and $1.5 \mathrm{~m}$ high with a $5 \mathrm{~m}$ base in the case of the composting (only tree litter). Table 1 shows the raw materials used, their weights, proportion, and composting days.

\subsubsection{Characterization of the Raw Materials of the Evalua-} tion Stage. For the evaluation stage, physicochemical variables and the total contents of heavy metals and trace elements of interest $\left(\mathrm{HM}_{\mathrm{tot}}\right)$ were recorded in the raw materials prior to the beginning of the composting process, as shown in Table 2. Most of the physicochemical values for COW-M were higher than for TREE-L, except for humidity $(\mathrm{H} \%)$ and ammoniacal nitrogen $\left(\mathrm{NH}_{4}^{+}-\mathrm{N}\right)$. The organic matter (OM) content was $26.6 \%$ higher in COW-M than in TREE-L. The electrical conductivity (EC) in the COW-M was higher, due to the type of cattle feed. Similar results were found in Cáceres and Marfa [50]. TREE-L concentrations for most $\mathrm{HM}_{\text {tot }}$ exceeded COW-M, except for $\mathrm{Cu}$, Se, and $\mathrm{Zn}$. The total $\mathrm{Pb}$ content in the TREE-L was more than five times the value in COW-M. Ahmed et al. [51] also found an important difference between $\mathrm{Pb}$ in poultry manure $\left(1.3 \mathrm{mg} \cdot \mathrm{kg}^{-1}\right)$ and in sawdust $\left(16.0 \mathrm{mg} \cdot \mathrm{kg}^{-1}\right)$, more than twelve times the value. Soobhany et al. [52] obtained average total concentrations of $\mathrm{Cu}$ and $\mathrm{Zn}$ lower values in leaves and dry branches $\left(84.3 \mathrm{mg} \cdot \mathrm{kg}^{-1}\right.$ and $65.3 \mathrm{mg} \cdot \mathrm{kg}^{-1}$ respectively) than in cattle manure $\left(137.1 \mathrm{mg} \cdot \mathrm{kg}^{-1}\right.$ and $596.0 \mathrm{mg} \cdot \mathrm{kg}^{-1}$ respectively) which is corroborated in the present results where the TREE-L had lower values than the COW-M in $\mathrm{Cu}$ and $\mathrm{Zn}$ (see Table 3), which, as mentioned above, may be due to the feed received by cattle and especially those used for milk production.

2.2.3. Generation, Inoculation, and Characterization of Beneficial Microorganisms in the Evaluation Stage. The generation of inoculum with BM was performed in two stages: the first was the generation of the stock solution (SS) and the second was the activation and enrichment of the SS for inoculation in the field. The SS or "efficient EM1 microorganisms" as Dr. Teruo Higa calls it [53] was prepared from cabbage leaf extract (Brassica oleracea L. var. capitata). In the second stage, nutrients were added and a bundle of plants. These plants were wrapped in silk textile to produce a filtrate that was decomposing and possibly contributing in the generation of BM in the SS. The plants were "rue" (Ruta graveolens L.), "horsetail" (Equisetum arvense L.), and "rosemary" (Rosmarinus officinalis L.). The plants selected 

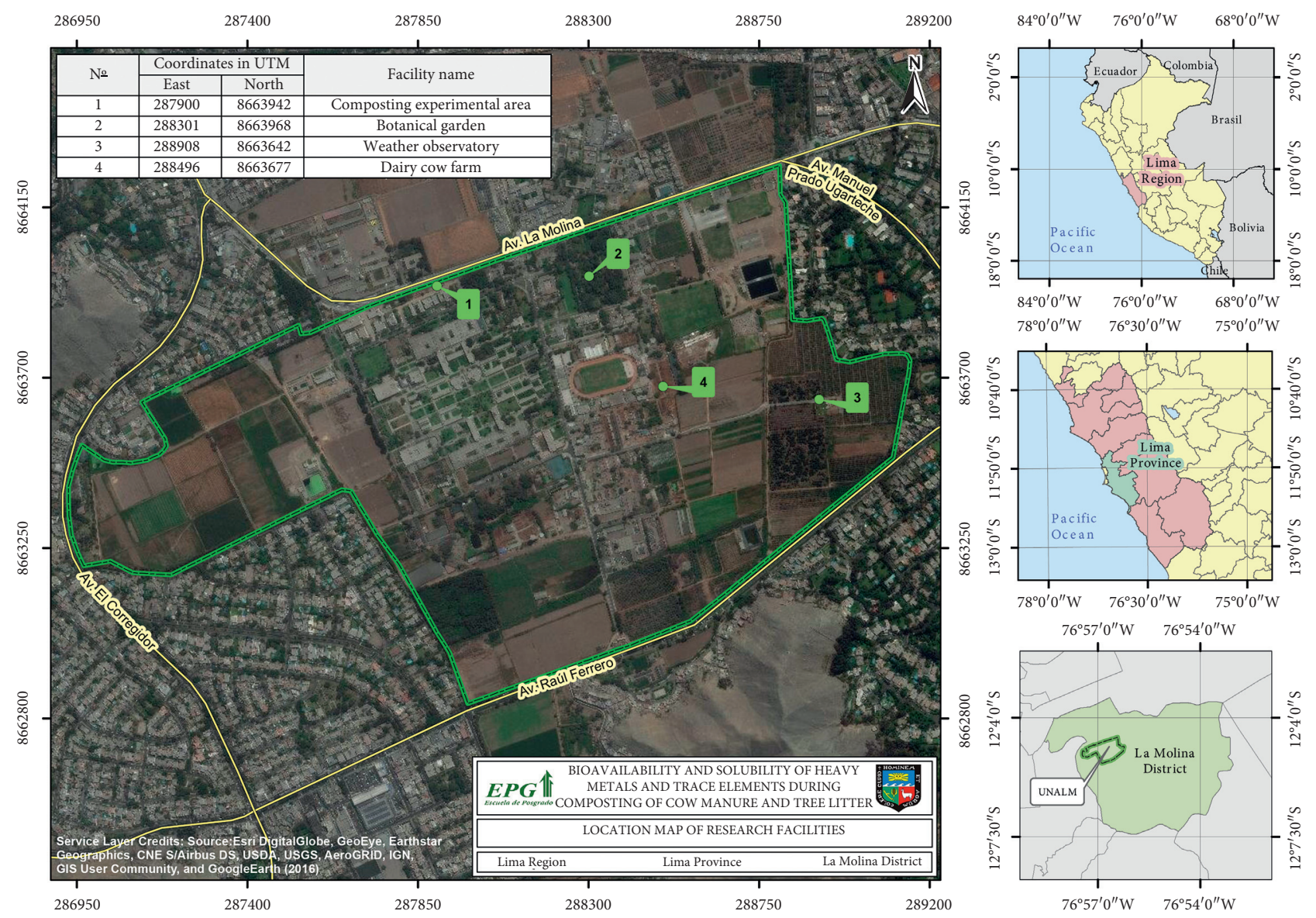

Figure 1: Satellite image of the university campus with the facilities which contributed to the investigation.

TABle 1: Raw materials for composting used in the investigation stages.

\begin{tabular}{|c|c|c|c|c|c|}
\hline Stage & Type of compost & $\begin{array}{c}\text { Raw } \\
\text { material }\end{array}$ & $\begin{array}{l}\text { Quantity in compost pile } \\
(\mathrm{kg})\end{array}$ & $\begin{array}{c}\text { Proportion } \\
(\%)\end{array}$ & $\begin{array}{l}\text { Composting time } \\
\text { (days) }\end{array}$ \\
\hline \multirow[t]{2}{*}{ Characterization } & $\begin{array}{c}\text { Co-compost of cow manure and grass } \\
\text { clipping }\end{array}$ & $\begin{array}{c}\text { Cow } \\
\text { manure } \\
\text { Grass } \\
\text { clipping }\end{array}$ & 200 & 40 & 111 \\
\hline & Compost of tree litter & Tree litter & 3000 & 100 & 240 \\
\hline \multirow{3}{*}{ Evaluation } & $\begin{array}{c}\text { Co-compost of cow manure and tree } \\
\text { litter IBM }\end{array}$ & $\begin{array}{c}\text { Cow } \\
\text { manure } \\
\text { Tree litter }\end{array}$ & 240 & 40 & 120 \\
\hline & \multirow{2}{*}{$\begin{array}{c}\text { Co-compost of cow manure and tree } \\
\text { litter NBM }\end{array}$} & $\begin{array}{c}\text { Cow } \\
\text { manure }\end{array}$ & 240 & 40 & \multirow[t]{2}{*}{120} \\
\hline & & Tree litter & 360 & 60 & \\
\hline
\end{tabular}

TABLE 2: Physicochemical variables of raw materials used in the evaluation stage composting $(n=6)$.

\begin{tabular}{|c|c|c|}
\hline Physicochemical variable & $\begin{array}{c}\text { Tree litter (TREE-L) } \\
\text { P 1-6 (mean } \pm \text { st. dev.) }\end{array}$ & $\begin{array}{l}\text { Cattle manure (COW-M) } \\
\text { P 1-6 (mean } \pm \text { st. dev.) }\end{array}$ \\
\hline $\mathrm{pH}<1 / 5>$ & $6.62 \pm 0.12$ & $7.77 \pm 0.14$ \\
\hline $\mathrm{H}(\%)$ & $37.21 \pm 2.04$ & $16.46 \pm 1.19$ \\
\hline $\mathrm{EC}<1 / 5>\left(\mathrm{dS} \mathrm{m}^{-1}\right)$ & $6.40 \pm 0.89$ & $14.17 \pm 0.80$ \\
\hline TOC (\%) & $29.01 \pm 4.36$ & $36.41 \pm 2.02$ \\
\hline $\mathrm{TN}(\%)$ & $1.45 \pm 0.10$ & $2.16 \pm 0.11$ \\
\hline $\mathrm{C} / \mathrm{N}$ & $20.14 \pm 3.16$ & $16.87 \pm 1.34$ \\
\hline HA (\%) & $1.61 \pm 0.40$ & $2.33 \pm 0.31$ \\
\hline FA $(\%)$ & $2.04 \pm 0.66$ & $3.56 \pm 0.28$ \\
\hline $\mathrm{NH}_{4}^{+}-\mathrm{N}\left(\mathrm{mg} \mathrm{kg}^{-1}\right)$ & $4.49 \pm 0.22$ & $2.30 \pm 0.23$ \\
\hline $\mathrm{OM}(\%)$ & $59.06 \pm 3.82$ & $74.25 \pm 0.92$ \\
\hline
\end{tabular}


TABLE 3: Heavy metals and trace elements of interest of the raw materials used in the evaluation stage composting $(n=6)$.

\begin{tabular}{lcc}
\hline Total contents of heavy metals and of trace elements of interest (HMtot) & $\begin{array}{c}\text { Tree litter (TREE-L) } \\
\text { P 1-6 (Mean } \pm \text { St. Dev.) }\end{array}$ & $\begin{array}{c}\text { Cattle manure (COW-M) } \\
\text { P 1-6 (Mean } \pm \text { St. Dev.) }\end{array}$ \\
\hline As $\left(\mathrm{mg} \cdot \mathrm{kg}^{-1}\right)$ & $28.17 \pm 3.13$ & $8.83 \pm 2.93$ \\
$\mathrm{Cd}\left(\mathrm{mg} \cdot \mathrm{kg}^{-1}\right)$ & $1.29 \pm 0.05$ & $0.34 \pm 0.03$ \\
$\mathrm{Cr}\left(\mathrm{mg} \cdot \mathrm{kg}^{-1}\right)$ & $26.50 \pm 3.02$ & $6.33 \pm 1.03$ \\
$\mathrm{Cu}\left(\mathrm{mg} \cdot \mathrm{kg}^{-1}\right)$ & $49.00 \pm 4.00$ & $94.67 \pm 27.85$ \\
$\mathrm{Hg}\left(\mathrm{mg} \cdot \mathrm{kg}^{-1}\right)$ & $0.30 \pm 0.03$ & $0.06 \pm 0.02$ \\
$\mathrm{Mo}\left(\mathrm{mg} \cdot \mathrm{kg}^{-1}\right)$ & $4.46 \pm 0.82$ & $4.27 \pm 0.17$ \\
$\mathrm{Ni}\left(\mathrm{mg} \cdot \mathrm{kg}^{-1}\right)$ & $7.18 \pm 0.57$ & $3.13 \pm 0.32$ \\
$\mathrm{~Pb}\left(\mathrm{mg} \cdot \mathrm{kg}^{-1}\right)$ & $59.00 \pm 5.34$ & $9.43 \pm 1.60$ \\
$\mathrm{Se}\left(\mathrm{mg} \cdot \mathrm{kg}^{-1}\right)$ & $0.56 \pm 0.04$ & $1.41 \pm 0.45$ \\
$\mathrm{Zn}\left(\mathrm{mg} \cdot \mathrm{kg}^{-1}\right)$ & $268.00 \pm 17.57$ & $313.00 \pm 70.24$ \\
\hline
\end{tabular}

for enrichment have medicinal properties and generate BM [54-58]. The activation procedure is as suggested by Dr. Teruo Higa [53] prior to definitive field application. The first inoculation was carried out with a $20 \%$ dilution. In other words, $4 \mathrm{~L}$ of the activated solution was taken and diluted in $20 \mathrm{~L}$ of water for the irrigation of piles P1, P2, and P3. Next, in each turning over, which was performed weekly, during the first month inoculation it was with a $1 \%$ dilution $(200 \mathrm{~mL}$ in $20 \mathrm{~L}$ ). That is to say, four inoculations were made at $1 \%$ (Figure 2). This inoculation process followed the guidelines mentioned by APROLAB [59] and OISCA-BID [53]. On days 0 (T0) and 30 (T30), samples were taken in triplicate from the activated stock solution (ASS) for microbiological analysis. On both occasions, the $\mathrm{pH}$ was measured, and an average of 3.21 and 3.19, respectively, was obtained (Figure 2). Figure " $a$ " of supporting information shows an image of the triplicate samples of the activated stock solution.

The average results are shown in Table 4 where it is observed that the presence of BM is in the order of millions, whereas the presence (Table 5) of pathogenic microorganisms (PM) is almost nil or minimal. On day 0 (T0) and day 30 (T30), the molds and yeasts were, respectively, independently counted. Alvarez [56] found on average for the yeasts in rue $5.5 \times 10^{4} \mathrm{UFC} \cdot \mathrm{mL}^{-1}$ and in rosemary $5.6 \times 10^{5} \mathrm{UFC} \cdot \mathrm{mL}^{-1}$, for Bacillus spp. $1.46 \times 10^{7} \mathrm{UFC} \cdot \mathrm{mL}^{-1}$ in rue and $6.67 \times 10^{5} \mathrm{UFC} \mathrm{mL}^{-1}$ in rosemary, for Lactobacillus spp. $6.43 \times 10^{12} \mathrm{UFC} \cdot \mathrm{mL}^{-1}$ in rue and $3.47 \times 10^{12} \mathrm{UFC} \cdot \mathrm{mL}^{-1}$ in rosemary, and for actinomycetes $8.67 \times 10^{3} \mathrm{UFC} \cdot \mathrm{mL}^{-1}$ in rue and $1.6 \times 10^{5} \mathrm{UFC} \cdot \mathrm{mL}^{-1}$ in rosemary. The results for the ASS of cabbage enriched with rue, rosemary, and horsetail are slightly higher in yeasts, slightly lower in Bacillus spp. and actinomycetes and significantly lower in Lactobacillus spp. than analyzed by Alvarez [56] for rue and rosemary but even so representing important values.

2.3. Methods. The variables analyzed and the methods of analysis are given below, followed by the chronology of the samples taken in each type of compost (Table 6). The results were obtained for homogenized samples composed of five subsamples (four vertices and crown) from the COW-M cocomposting piles (Figure " $b$ " of supporting information shows an image of the 120 day sampling), and for TREE-L alone, samples were composed of three subsamples taken from the base of the pile. The $500 \mathrm{~g}$ samples were collected in Ziplock $^{\mathrm{TM}}$ polypropylene bags which were sent to a laboratory for analysis in triplicate. In the case of microbiological variables, they were also analyzed in triplicate. The viability time was 24 hours, and all were delivered within 12 hours of collection.

2.3.1. Analyzed Secondary Variables. Twenty-three secondary variables were analyzed, eleven physicochemical and twelve microbiological ones.

(1) Physicochemical Variables. Made up of eleven (11) variables: moisture (H\%) using TMECC method 03.09-A-total solids and moisture at $70 \pm 5^{\circ} \mathrm{C}$ [60]; hydrogen potential $(\mathrm{pH})$ using the TMECC method 04.11-A electrometric $\mathrm{pH}$ determination for compost [60]; electrical conductivity (EC) using the TMECC method 04.10 electrical conductivity for compost 1:5 [60]; total organic carbon (TOC) using the Walkey and Black method [61]; organic matter (OM) by TMECC 05.07-A loss on ignition method [60]; total nitrogen (TN) using the Kjedahl method [62]; ammonium nitrogen $\left(\mathrm{NH}^{+}-\mathbf{N}\right)$ using method 8.2.1 Rev. 2005 [63]; and humic acid fraction (HA) and fulvic acid fraction (FA) using the standardized KononovaBelchikova method [64]. Apparent density (Da) was determined by the known volume cylinder method [65]. The temperature $\left(\mathrm{T}^{\mathbf{o}}\right)$ was recorded in situ using a digital thermometer, ST-9265 multithermometer (13 cm long sensor and $1^{\circ} \mathrm{C}$ precision), taking measurements in five zones of each pile (four vertices and crown) from which a mean was obtained.

(2) Microbiological Variables. Consists of twelve variables: mesophilic aerobes; thermophilic aerobes; Lactobacillus spp.; molds and yeasts; total coliforms; fecal coliforms; Escherichia coli; and Salmonella spp. using ICMSF test method [66]; Pseudomonas spp., Bacillus spp., and actinomycetes by the APHA analysis methods [67] and helminths using the standards methods for the recovery and enumeration of helminth ova in wastewater, sludge, compost, and urine-diversion waste in South Africa [68].

2.3.2. Analyzed Primary Variables. The thirty primary variables are made up of three groups that group the ten elements under analysis (As, Cd, Cu, Cr, Hg, Ni, Mo, Pb, Se, and $\mathrm{Zn}$ ). 


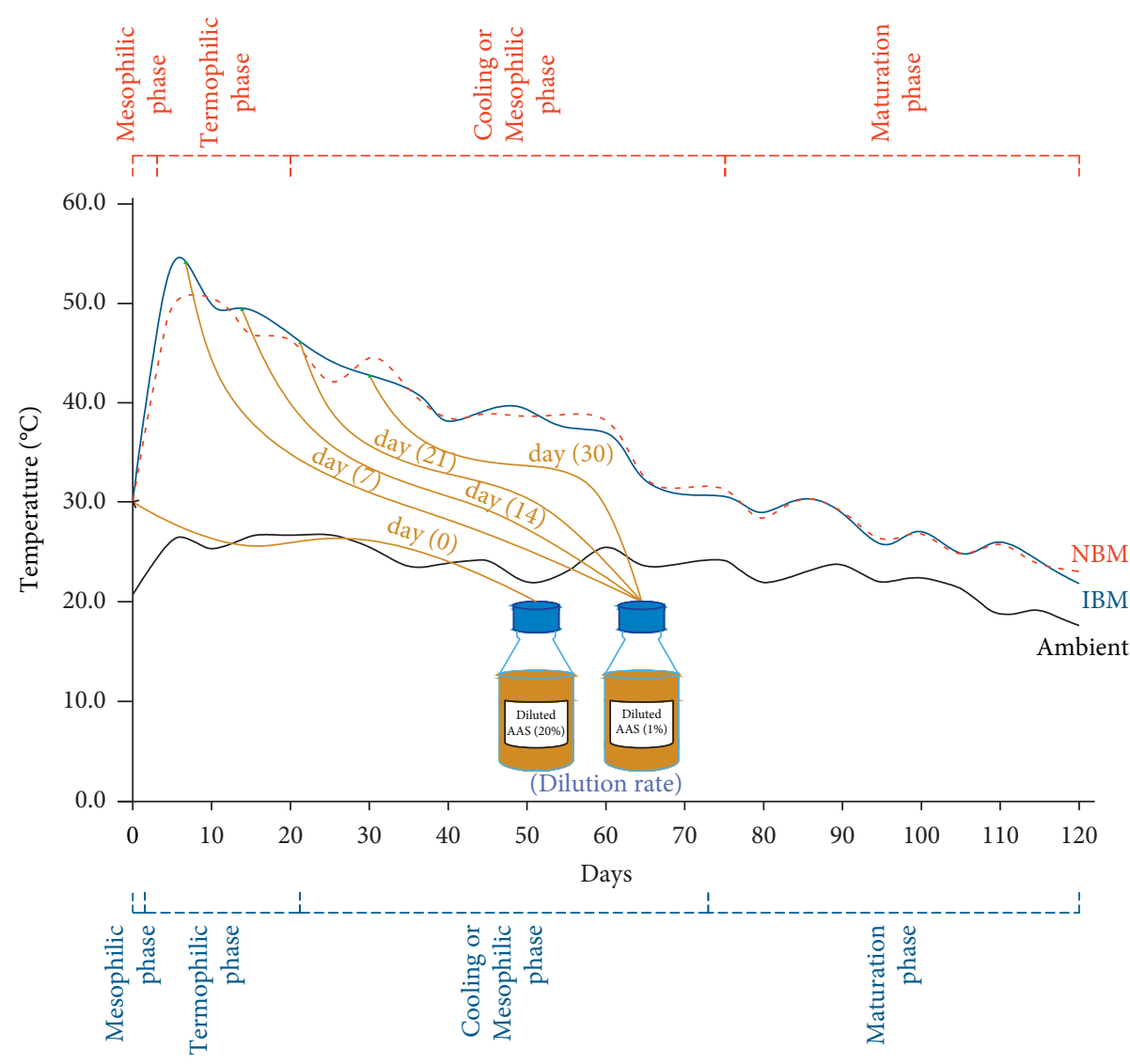

FIGURE 2: Days of inoculation of the compost piles with diluted activated stock solution (ASS), phases of the composting process and temperatures of the inoculated (IBM), and noninoculated (NBM) piles and the ambient temperature.

TABLE 4: Microbiological analysis of beneficial micro-organisms-BM in the activated stock solution-ASS $(n=3)$.

\begin{tabular}{lcr}
\hline Parameters & T0 & T30 \\
& Mean \pm st. dev. & Mean st. dev. \\
\hline Mesophilic aerobes (UFC. $\mathrm{mL}^{-1}$ ) & $1.25 \times 10^{7} \pm 4.01 \times 10^{6}$ & $4.33 \times 10^{6} \pm 1.10 \times 10^{6}$ \\
Thermophilic aerobes (UFC.mL $\mathrm{mL}^{-1}$ ) & $3.00 \times 10^{4} \pm 4.35 \times 10^{4}$ & $5.00 \times 10^{3} \pm 4.23 \times 10^{3}$ \\
Lactobacillus spp. (UFC.mL ${ }^{-1}$ ) & $1.27 \times 10^{7} \pm 2.08 \times 10^{6}$ & $1.00 \times 10^{7} \pm 5.33 \times 10^{6}$ \\
Molds and yeasts (UFC. $\mathrm{mL}^{-1}$ ) & $<1.00 \times 10^{2} \pm 0.00$ & $1.27 \times 10^{6} \pm 8.50 \times 10^{5}$ \\
Bacillus spp. (UFC. $\mathrm{mL}^{-1}$ ) & $1.00 \times 10^{2} \pm 0.00$ & $1.77 \times 10^{6} \pm 3.06 \times 10^{6}$ \\
Actinomycetes (UFC $\cdot \mathrm{mL}^{-1}$ ) & $1.01 \times 10^{5} \pm 1.11 \times 10^{5}$ & $1.60 \times 10^{3} \pm 5.66 \times 10^{2}$ \\
\hline
\end{tabular}

TABLE 5: Microbiological analysis of pathological microorganisms PM in the activated stock solution ASS $(n=3)$.

\begin{tabular}{lcc}
\hline Parameters & T0 & T30 \\
& Mean \pm st. dev. & Mean \pm st. dev. \\
\hline Total coliforms (NMP. $\mathrm{mL}^{-1}$ ) & $<3.00 \pm 0.00$ & $<3.00 \pm 0.00$ \\
Fecal coliforms (NMP.mL $\mathrm{mL}^{-1}$ ) & $<3.00 \pm 0.00$ & $<3.00 \pm 0.00$ \\
Pseudomonas spp. $\left(\mathrm{NMP} \cdot \mathrm{mL}^{-1}\right)$ & $<3.00 \pm 0.00$ & $<3.00 \pm 0.00$ \\
Escherichia coli $\left(\mathrm{NMP} \cdot \mathrm{mL}^{-1}\right)$ & $<3.00 \pm 0.00$ & $<3.00 \pm 0.00$ \\
Detection of Salmonella spp. $(25 \mathrm{~mL})$ & Absent \pm-- & Absent \pm-- \\
Larvae and eggs of helminths, cysts, and oocysts of pathogenic protozoa $(\mathrm{N} / 4 \mathrm{~mL})$ & $0.67 \pm 1.15$ & $1.87 \times 10^{1} \pm 6.11$ \\
\hline
\end{tabular}

(1) Total Concentration of Heavy Metals and Trace Elements of Interest $\left(H M_{t o t}\right)$. Analysed by the method 3050B [69] acid digestion of sediments, sludge, and soils and method 6020A [70] inductively coupled plasma mass spectrometer.
(2) Concentration of Heavy Metals and Trace Elements of Interest Extracted with Pentatetic Acid (HM $\left.M_{D T P A}\right)$. Solid/ extractant ratio 1:5 $(p / v)$ for two hours with $0.005 \mathrm{M}$ DTPA (diethylenetriamine pentaacetic acid acquired from MERCK $\mathrm{KGaA}^{\mathrm{TM}}$ ) plus $0.1 \mathrm{M}$ TEA (triethanolamine acquired from 
TABLE 6: Recorded parameters and measurement dates for each stage of the investigation.

\begin{tabular}{|c|c|c|c|}
\hline Stage & Primary variables & Secondary variables & Measurement date \\
\hline Characterization & Total content $\left(\mathrm{HM}_{\mathrm{tot}}\right)$ & Four physicochemical variables (pH, EC, TOC, and TN) & $\begin{array}{c}\text { February 13, } 2014 \\
\text { (T111/T240) }\end{array}$ \\
\hline Evaluation & $\begin{array}{l}\text { Total content }\left(\mathrm{HM}_{\mathrm{tot}}\right) \text {, } \\
\text { Bioavailability }\left(\mathrm{HM}_{\mathrm{DTPA}}\right) \text { and } \\
\text { solubility }\left(\mathrm{HM}_{\mathrm{H} 2 \mathrm{O}}\right)\end{array}$ & $\begin{array}{l}\text { Eleven physicochemical variables }\left(\mathrm{T}^{\circ}, \mathrm{H} \% \text {, pH, EC, TOC, }\right. \\
\left.\text { TN, } \mathrm{NH}_{4}^{+}-\mathrm{N}, \mathrm{HA}, \mathrm{FA}, \mathrm{OM} \text {, and } \mathrm{Da}\right) \\
\text { Twelve microbiological variables (mesophilic aerobes, } \\
\text { thermophilic aerobes, Lactobacillus spp., molds and yeasts, } \\
\text { total coliforms, fecal coliforms, Escherichia coli, Salmonella } \\
\text { spp., Pseudomonas spp., Bacillus spp., actinomycetes, and } \\
\text { helminths) }\end{array}$ & $\begin{array}{c}\text { February 2, } 2016 \\
\text { (T0); } \\
\text { March 3, } 2016 \\
\text { (T30); } \\
\text { April 2, 2016 (T60); } \\
\text { May 2, } 2016 \text { (T90); } \\
\text { June 1, } 2016 \text { (T120) }\end{array}$ \\
\hline
\end{tabular}

MERCK $\mathrm{KGaA}^{\mathrm{TM}}$ ) and $0.01 \mathrm{M} \mathrm{CaCl}_{2}$ at $\mathrm{pH} 7.3$ with diluted $\mathrm{HCl}$. The compost extract was stored in plastic vials at $4^{\circ} \mathrm{C}$ for further analysis [21].

(3) Concentration of Heavy Metals and Trace Elements of Interest Extracted with Deionized Water $\left(\mathrm{HM}_{\mathrm{H} 2 \mathrm{O}}\right) .1 \mathrm{~g}$ of compost sample was taken. The sample was extracted with $15 \mathrm{~mL}$ of deionized water (by reverse osmosis and ion exchange with $\mathrm{EC}<1 \mu \mathrm{S} \cdot \mathrm{m}^{-1}$ ) by mechanical agitation at $120 \mathrm{rpm}$ for two hours and then centrifuged at $4000 \mathrm{rpm}$ for 5 minutes. It was filtered with a $0.45 \mu \mathrm{m}$ nylon membrane. The compost extract was stored in plastic vials at $4^{\circ} \mathrm{C}$ for further analysis [21].

Analyses of the digestates of the primary variables were performed on a Perkin Elmer spectrometer, model Elan DRC-e. Table 6 shows the stages of the investigation, primary variables, secondary variables, and measurement dates.

2.4. Statistical Analysis (Evaluation Stage). The experimental design of the investigation in its evaluation stage was completely randomized (completely randomized design). The investigation considered the IBM and NBM factors, five treatments (composting days: 0, 30, 60, 90, and 120), and three repetitions (composting piles). Fifty-three variables have been evaluated, divided into thirty main variables and twenty-three (23) secondary variables. Table " $a$ " of supporting information shows factors, treatments, and their respective coding.

2.4.1. Secondary Variables. Twelve physicochemical variables (H\%, pH, EC, TOC, TN, C/N ratio, HA, FA, HA/FA ratio, $\mathrm{NH}_{4}^{+}-\mathrm{N}, \mathrm{OM}$, and $\mathrm{Da}$ ) were registered. $\mathrm{T}^{\circ}$ was discarded due to the nonexistence in the literature of information concerning its influence on the bioavailability of the heavy metals and trace elements of interest, and the $\mathrm{C} /$ $\mathrm{N}$ and HA/FA rates used to determine the maturation of compost were incorporated [17]. Eleven microbiological variables include mesophilic aerobes, thermophilic aerobes, Lactobacillus spp., molds and yeasts, Pseudomonas spp., Bacillus spp., actinomycetes, total coliforms, fecal coliforms, Escherichia coli, and helminths. The variable Salmonella spp. was withdrawn from the statistical analysis as its results are qualitative.
2.4.2. Primary Variables. Primary variables are thirty principal variables considering the three analysis groups $\left(\mathrm{HM}_{\mathrm{tot}}, \mathrm{HM}_{\mathrm{DTPA}}\right.$ and $\left.\mathrm{HM}_{\mathrm{H} 20}\right)$ and the ten elements under analysis (As, Cd, Cr, Cu, Hg, Mo, Ni, Pb, Se, and Zn).

2.4.3. Analysis of the Variables. The analysis of the (primary and secondary) variables was carried out using the decomposition technique of the variability of the data called analysis of variance (ANOVA). This test allowed the comparison of the mean concentration or units of each variable at different composting days (treatments) on the basis of the completely randomized design, or factor design, used in this investigation. For correct application, the ANOVA of a factor requires compliance with the assumption of normal distribution and homogeneity of variances [71]. The AndersonDarling test was used or the verification of normality and the Bartlett test for homogeneity. For the compliance with both assumptions, the $p$ value associated with each of these tests should be greater than the level of significance, 0.05. The ANOVA analysis was performed when it was verified that the two assumptions, variance homogeneity and normal distribution, were met. When these assumptions were not met, it was decided to use the KruskalWallis Test or nonparametric method or free distribution [71]. These analyses were carried out using the statistical software $\mathrm{R}^{\mathrm{TM}}$ Version 3.3.2.

In order to analyze how primary and secondary physicochemical variables vary with respect to the application factors of beneficial microorganisms and treatments, general linear and mixed models were made to consider the heterogeneity of variance during the analyzed period. Then, the most appropriate model was selected using the values of Akaike (AIC), Schwarz (BIC), and the maximum likelihood test (LRT) [72]. For all measured variables, normality was analyzed using the ShapiroFrance test [73]. In the case of microbiological secondary variables, generalized linear binomial negative models were used [72]. In order to study the degree of association between primary and secondary variables, the Pearson linear correlation coefficient was used in those variables that did not show influence by the inoculation factor. This comparative value is reinforced with the $p$ value (if it is $<0.05$, it is significant and if it is $>0.05$, it is not significant). This correlation was obtained by processing the information with the InfoStat ${ }^{\mathrm{TM}}$ software, version 2017.1.2. Correlations were evaluated between the 53 variables, all against all. For the present article, the primary variables were 
selected that exceeded the correlation of 0.5 , positive or negative, in relation to the fraction of humic acids (AHs).

Using the InfoStat ${ }^{\mathrm{TM}}$ software, version 2017.1.2, an unrestricted sorting analysis was made of the principal components. Fifty-three variables were used for this (primary and secondary, excepting Sallmonella spp. as it has qualitative values) initially through a first run, where abundant values greater than 1 were obtained. From this, a reduction of variables was made, through the ordering of the variables and their weights in the first components, working with the absolute values and observing which variables have greater weight in the first two components. From this new arrangement, two autovalues with values greater than 1 were obtained (the variables that had less weight in the first two axes were eliminated). Finally, the variables obtained for components 1 and 2 explain $78 \%$ of the variance.

\section{Results}

\subsection{Characterization Stage}

3.1.1. Secondary Variables (Physicochemical). The results of the recorded physicochemical variables $(\mathrm{pH}, \mathrm{EC}, \mathrm{TOC}, \mathrm{TN}$, and $\mathrm{C} / \mathrm{N}$ ratio) of the compost products (T111/T240) of the characterization stage are shown in Figure 3. It is observed that, in all mean values, manure compost exceeds tree litter. Compared with the Chilean standard [74], we have the $\mathrm{pH}$ complying for both types of compost and both classes (A and $\mathrm{B}$ ); for the EC, only tree litter complies for class B compost; $\mathrm{TN}$ is complied with for both types of compost and for both classes, and the $\mathrm{C} / \mathrm{N}$ ratio is met in both types of compost and for both classes. It is important to emphasize the value of $\mathrm{CE}$, which can be associated with the type of cattle feed [75]. This presence of EC in this type of manure can generate the increase of this value in the soils where it is applied, in the medium or long term, which can generate processes of salinization and infertility $[76,77]$.

\subsubsection{Primary Variables (Total Content of Heavy Metal and} Trace Elements of Interest). The $\mathrm{HM}_{\mathrm{tot}}$ of the TREE-L composting product (T120) showed the following order in its mean values $\left(\mathrm{mg} \cdot \mathrm{kg}^{-1}\right): \mathrm{Zn}(533.79)>\mathrm{Pb}(173.32)>\mathrm{Cu}$ $(83.32)>\mathrm{As}(73.78)>\mathrm{Cr}(31.739>\mathrm{Ni}(8.49)>\mathrm{Se}(3.02)>\mathrm{Cd}$ (2.10) $>\mathrm{Mo}(2.04)>\mathrm{Hg}$ (0.76). In the COW-M and GRASSC T120 compost: $\mathrm{Zn}(404.56)>\mathrm{Pb}(67.26)>\mathrm{Cu}(59.91)>\mathrm{As}$ $(38.09)>\mathrm{Cr}(9.54)>\mathrm{Ni}(6.64)>\mathrm{Mo}(2.14)>\mathrm{Se}(1.65)>\mathrm{Cd}$ (1.15) $>\mathrm{Hg}(0.35)$. The $\mathrm{HM}_{\text {tot }}$ values in the TREE-L compost are higher than in the COW-M and GRASS-C compost. In the cases of $\mathrm{Cr}$ and $\mathrm{Pb}$ for TREE-L compost, it exceeds by more than three and two times the mean value of the COW$\mathrm{M}$ and GRASS-C compost, respectively (Figure 4). The higher $\mathrm{HM}_{\text {tot }}$ value in the compost generated from the TREE-L of the Botanical Garden of the UNALM shows what was pointed out by several authors $[7,25-30]$ on the retention of these elements in the foliage due to the precipitation of atmospheric dust. The botanical garden, due to its

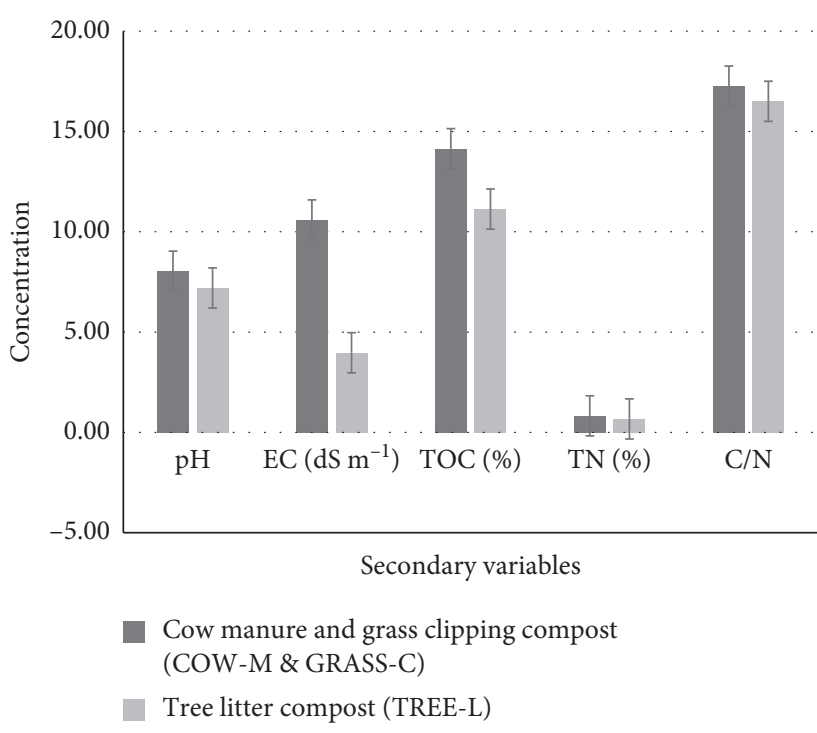

FIgURE 3: Mean values of physicochemical variables of cow manure and grass clipping compost, and tree litter compost $(n=3)$.

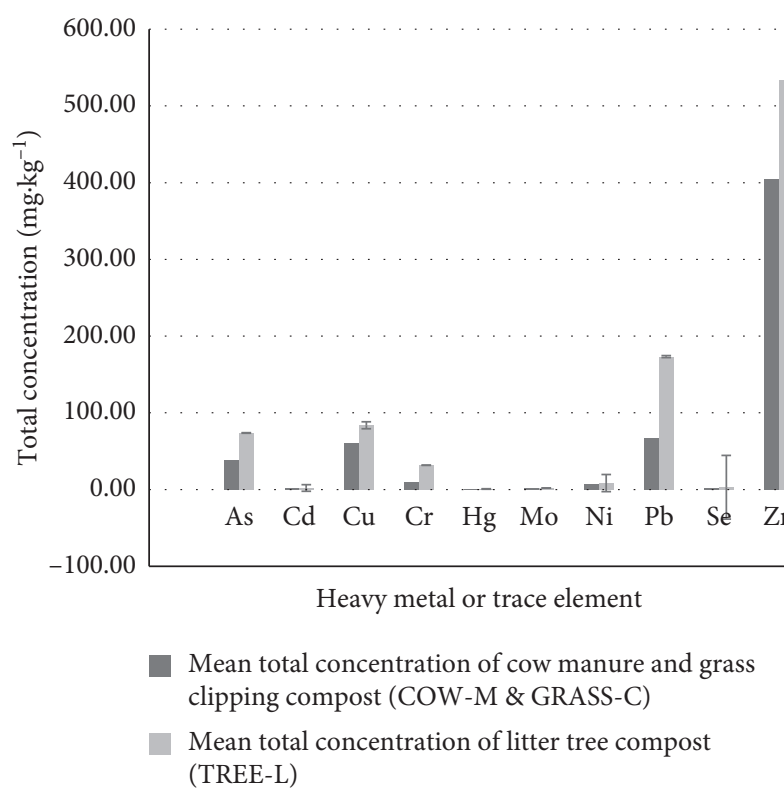

FIGURE 4: Mean concentration of heavy metals and trace elements of interest in cow manure compost and grass clipping vs tree litter compost $(n=3)$.

proximity to La Universidad Avenue, acts as a "biofilter" for the university due to the retention of these pollutants. On the other hand, the compost generated from COW-M and GRASS-C, not being exposed at the same intensity and frequency to air pollution, shows lower levels of heavy metals, but $\mathrm{Cu}$ and $\mathrm{Zn}$ do show a significant presence due to the feeding of dairy cattle [32-36].

This stage was carried out 24 months before the evaluation stage, giving knowledge of the concentration of heavy 
metals and trace elements of interest in significant amounts in the TREE-L compost, so it was decided to use this raw material for the next (evaluation) stage mixed with COW-M.

\subsection{Evaluation Stage}

3.2.1. Secondary Variables (Microbiological). Changes were observed in the distribution of the microbial population during the composting process influenced by the physicochemical variables, in principle, the temperature, the presence of nutrients $(\mathrm{C} / \mathrm{N}$ rate variation), and the $\mathrm{pH}$, which have been properly documented and referenced by Moreno and Moral [17] and Ch'ng et al. [78] in the normal development of aerobic composting. It can be inferred that the levels of heavy metals and trace elements of interest, due to the recorded concentrations, should not have significantly negatively influenced the metabolic activity of microbial populations, and, it is possible, it rather influenced in the opposite direction. For the latter, Reddy et al. [79] mention that metal tolerances of bacteria were for As $255-355 \mathrm{mg} \cdot \mathrm{kg}^{-1}$, for Cd $10-35 \mathrm{mg} \cdot \mathrm{kg}^{-1}$, for $\mathrm{Zn}$ 215-320 mg. $\mathrm{kg}^{-1}$, for $\mathrm{Hg} 278-315 \mathrm{mg} \cdot \mathrm{kg}^{-1}$, and for $\mathrm{Pb}$ $3450-4010 \mathrm{mg} \cdot \mathrm{kg}^{-1}$. Only in the case of $\mathrm{Zn}$ are there recorded values that exceeded these tolerance levels.

Two figures of microbiological variables with the physicochemical variables $\mathrm{HA}, \mathrm{pH}$, ratio $\mathrm{C} / \mathrm{N}$, and $\mathrm{T}^{\circ}$ have been added in order to be able to see the behavior during the composting process of the average values in the IBM and NBM piles. Figure 5 groups the microbiological variables that were counted as colony-forming units per gram $\left(\mathrm{CFU} \cdot \mathrm{g}^{-1}\right)$ and Figure 6 as most probable number per gram $\left(\mathrm{MPN} \cdot \mathrm{g}^{-1}\right)$. These grouped figures do not consider the variable Salmonella spp. as it has qualitative values nor the helminths as they have a differentiated accounting to the groupings. The first group figure, considered also as BM, is made up of mesophilic aerobes and thermophilic aerobes, Bacillus spp., Lactobacillus spp., molds and yeasts, and actinomycetes, considering the order of descending population magnitude, and the second figure, considered also as PM, of Pseudomonas spp., total coliforms, fecal coliforms, and Escherichia coli, considering the order of descending population magnitude. As can be seen at the beginning of the process (Day 0), the population of microorganisms is higher than that observed at the end of the composting process (Day 120). In the cases of the second grouping, it is important to observe the reduction of pathogens such as fecal coliforms, which are the only microbiological variables that showed a statistically significant $(p<0.05)$ reduction in its population in the IBM and NBM piles. These population changes with significant values at the beginning and decreasing during the composting process have also been observed by Ahmed et al. [80] and Haroun et al. [81]. The sterilization of pathogens in composting piles is related to the maximum temperatures reached and the retention time $[17,41,51]$. In both types of piles, the temperature reached $56^{\circ} \mathrm{C}$ (Figure 2), but in IBM, the thermophilic phase lasted 20 days, while in NBM, it lasted 18 days and in no case was the temperature in the range of 60 to $70^{\circ} \mathrm{C}$, which is recommended for the sterilization of the majority of pathogens $[17,51]$. Despite this, the maximum values recommended by the Peruvian regulations $[82,83]$ were met in the IBM piles, except for helminths, and the NBM piles also did not reach the value for eliminating total coliforms in the composting product (Day 120).

3.2.2. Primary Variables. The results of the 10 metals and trace elements of interest, the main variables of this investigation, are presented graphically and described in grouped and differentiated form in $\mathrm{HM}_{\text {tot }}, \mathrm{HM}_{\mathrm{DTPA}}$, and $\mathrm{HM}_{\mathrm{H} 2 \mathrm{O}}$ for the IBM and NBM piles and the physicochemical variables $\left(\mathrm{pH}, \mathrm{T}^{\circ}, \mathrm{C} / \mathrm{N}\right.$ ratio, and $\left.\mathrm{HA}\right)$.

The mean values of the total concentrations of heavy metals and trace elements of interest in the products of the composting (Day 120) of the COW-M and the TREE-L IBM have the following order $\left(\mathrm{mg}^{\mathrm{kg}} \mathrm{kg}^{-1}\right) \mathrm{Zn}(404.33)>\mathrm{Cu}$ $(86.33)>\mathrm{Pb}(71.2)>\mathrm{Cr}(34.33)>\mathrm{As}(28.0)>\mathrm{Ni}(13.83)>\mathrm{Mo}$ $(2.86)>\mathrm{Se}(1.38)>\mathrm{Cd}(1.32)>\mathrm{Hg}(0.39)$. In the products of composting of COW-M and TREE-L NBM, there was the following order $\left(\mathrm{mg}^{\mathrm{kg}}{ }^{-1}\right): \mathrm{Zn}(466.0)>\mathrm{Cu}(112.23)>\mathrm{Pb}$ (73.23) $>\mathrm{Cr}(35.33)>\mathrm{As}(29.67)>\mathrm{Ni}(14.37)>\mathrm{Mo}$ (3.23) $>\mathrm{Se}(1.55)>\mathrm{Cd}(1.38)>\mathrm{Hg}(0.38)$ (Figure 7). $\mathrm{Cd}, \mathrm{Pb}$, and $\mathrm{Zn}$ exceeded the values of the Austrian Standard [84] for compost with organic agriculture in IBM and NBM, just as it as found with $\mathrm{Cu}$ in NBM. In addition, As also exceeded the Brazilian Standard [85] for compost with organic agriculture in IBM and NBM. Nevertheless, the compost complied with it for landscaping and land rehabilitation of the Austrian Standard, and also with Peru's regulations $[82,83]$ for compost for nonorganic agriculture.

The hierarchical distribution of the elements differs from the one observed in the products of composting in the characterization stage, as although for the four composts $\mathrm{Zn}$ is the highest, $\mathrm{Pb}$ is the second, displacing $\mathrm{Cu}$ to third place, followed by As in fourth place (Section 3.1.2). Ciavatta et al. [40] found distributions of the average concentration $\left(\mathrm{mg}^{\mathrm{kg}} \mathrm{kg}^{-1}\right)$ of heavy metals, in compost from municipal household waste in Italy during 55 days of composting in an aerated static pile, in summer: $\mathrm{Zn}(1037)$ $>\mathrm{Pb}(981)>\mathrm{Cu}>(737)>\mathrm{Cr}(162)>\mathrm{Cd}(6,7)$ and in winter: $\mathrm{Zn} \quad(981)>\mathrm{Cu} \quad(399)>\mathrm{Pb} \quad(287)>\mathrm{Cr} \quad(69)>\mathrm{Ni} \quad(47)>\mathrm{Cd}$ (3.9). Hanc et al. [24] recorded at the end of 84 days of composting household waste with garden waste in a reactor with medium aeration that the average concentration values $\left(\mathrm{mg} \cdot \mathrm{kg}^{-1}\right)$ were $\mathrm{Zn}(167.1)>\mathrm{Cu}(29.1)>\mathrm{Pb}>(16.9)$ $>\mathrm{Cd}(0.27)$. In both investigations, $\mathrm{Zn}$ leads the total concentration values, and the other three are $\mathrm{Cu}, \mathrm{Pb}$, and $\mathrm{Cr}$, similar to those recorded in this investigation. The sums of the means of the ten elements of interest on day 0 for IBM and NBM (mg. $\mathrm{kg}^{-1}$ ) were $501.03 \pm 65.77$ and $520.53 \pm 35.22$, and on day 120 , they presented values of $643.98 \pm 20.72$ and $737 \pm 60.95$, respectively. This meant an average increase of $28.53 \%$ and $41.66 \%$ for IBM and NBM, respectively.

The percentage increase of the concentration from day 0 to 120 in IBM piles was in the following order: Se $(112.3 \%)$ $>\mathrm{Ni}(78.0 \%)>\mathrm{Pb}(49.5 \%)>\mathrm{Cr}(43.0 \%)>\mathrm{Zn}(41.5 \%)>\mathrm{Cd}$ $(40.4 \%)>\mathrm{Hg} \quad(34.5 \%)>$ As $\quad(9.1 \%)$. The concentration 


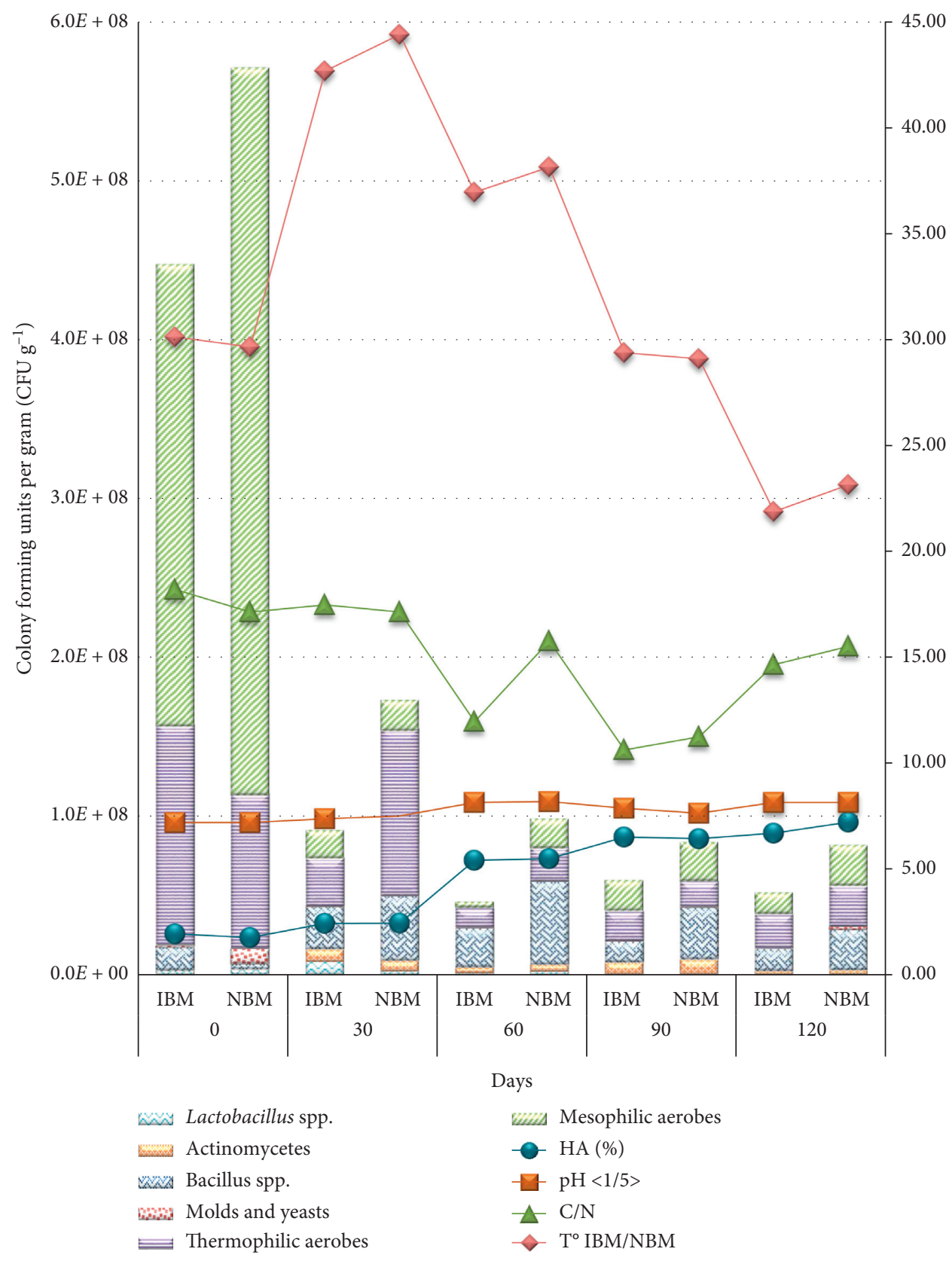

Figure 5: Microbiological variables counted as colony-forming units per Gram (CFU.g ${ }^{-1}$ ) during composting of cow manure and tree litter in inoculated (IBM) and noninoculated (NBM) piles and physicochemical variables ( $\mathrm{HA}, \mathrm{pH}, \mathrm{C} / \mathrm{N}$ ratio and $\left.\mathrm{T}^{\circ}\right)$. ${ }^{*}$ For the purposes of the composition of the figure, the data for molds and yeasts on day 0 in the noninoculated piles (NBM) were divided by 1000 .

reduction for these piles is $\mathrm{Mo}(43.7 \%)>\mathrm{Cu}(16.5 \%)$. The percentage increase of the concentration from day 0 to 120 in NBM piles was in the following order: $\mathrm{Ni}(105.3 \%)>\mathrm{Se}$ $(96.2 \%)>\mathrm{Cu} \quad(48.3 \%)>\mathrm{Zn} \quad(46.2 \%)>\mathrm{Cd} \quad(36.6 \%)>\mathrm{Hg}$ $(35.7 \%)>\mathrm{Cr}(35.9 \%)>\mathrm{Pb}(27.7 \%)>\mathrm{As}(2.3 \%)$. The only concentration reduction for these piles was of Mo at $32.6 \%$. Statistical significance $(p<0.05)$ was observed in the increase of $\mathrm{Hg}$, Se, and $\mathrm{Zn}$ and the reduction in Mo for both types of pile. There is no trend in the variations indicating any influence of inoculation with $\mathrm{BM}$, but there was found differences among 120 days samples of $\mathrm{Cu}$. The increase in concentration could be due to the loss of mass resulting from mineralization and volatilization of carbon and nitrogen [17, 21, 52, 86, 87]. The reduction in Mo may be associated with the effect of the $\mathrm{pH}$ on its mobility and possible leaching [88]. Ciavatta et al. [40] showed an increase in the summer in the sequence: $\mathrm{Ni}(752 \%)>\mathrm{Pb}$ $(554 \%)>\mathrm{Cd}(379 \%)>\mathrm{Cu}(303 \%)>\mathrm{Zn}(66 \%)$; in winter: $\mathrm{Cd}(550 \%)>\mathrm{Ni}(104 \%)>\mathrm{Zn}(77 \%)>\mathrm{Cr}(47 \%)>\mathrm{Cu}(19 \%)$ $>\mathrm{Pb}(6 \%)$. Hanc et al. [24] observed that the order of increases was $\mathrm{Zn}(84 \%)>\mathrm{Cu}(49 \%)>\mathrm{Pb}(22 \%)$; in the case of $\mathrm{Cd}$, there was a reduction of $4 \%$. Similar to this investigation, most of the average total concentrations of heavy metals increased at the end of the composting process, although with differences in the incremental values, by type of compost and season. 


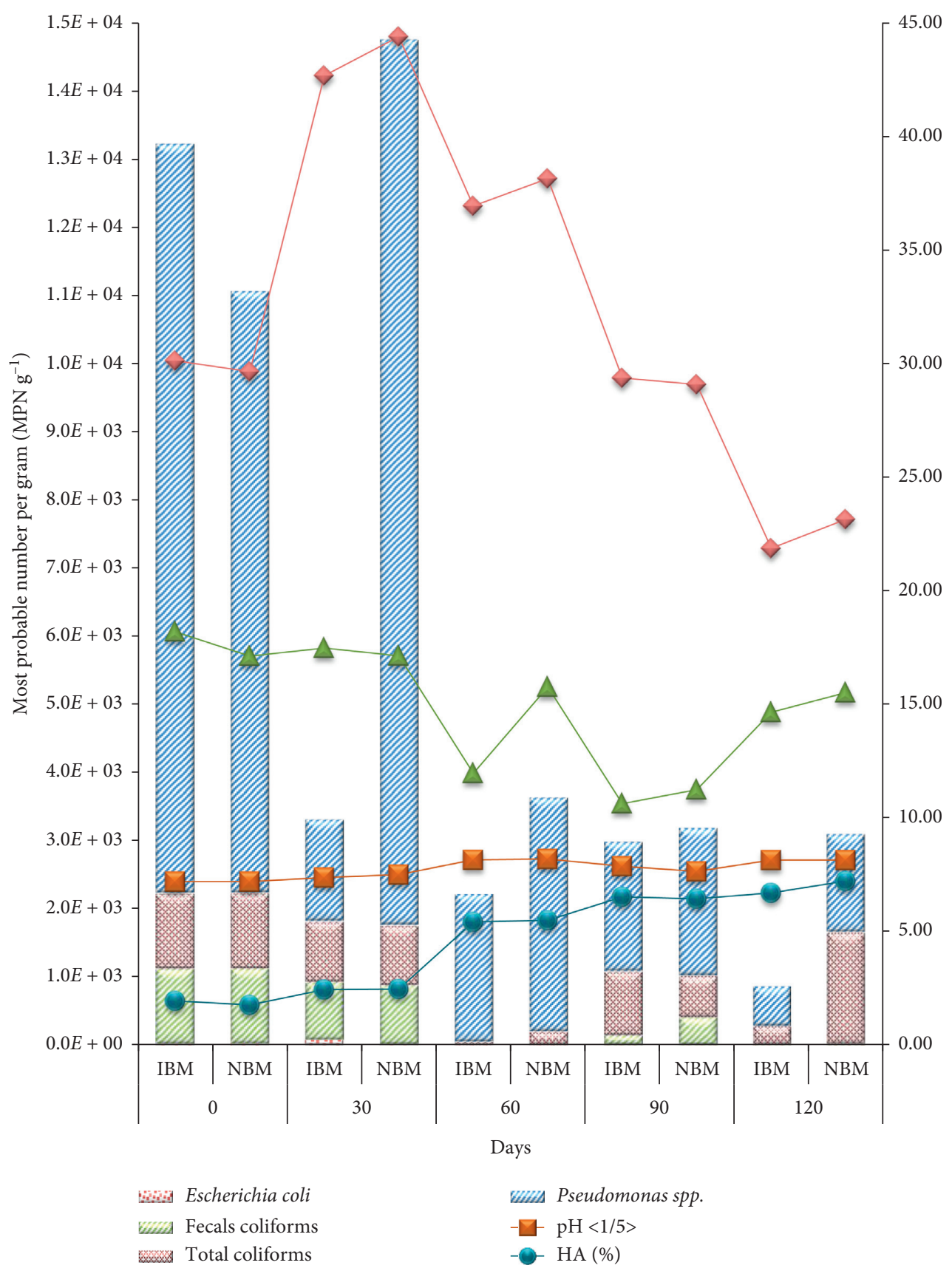

FIGURE 6: Microbiological variables counted as most likely number per gram (NMP.g ${ }^{-1}$ ) during composting of cow manure and tree litter in piles inoculated with beneficial microorganisms (IBM) and in noninoculated piles (NBM) and physicochemical variables (HA, $\mathrm{pH}$, temperature, and $\mathrm{C} / \mathrm{N}$ ratio).

The mean values of concentration of heavy metals and trace elements of interest extracted with DTPA from the COW-M and the TREE-L IBM composts (Day 120) had the following order $\left(\mathrm{mg}^{\mathrm{kg}} \mathrm{kg}^{-1}\right) \mathrm{Zn}(91.59)>\mathrm{Pb}(24.50)>\mathrm{Cu}$ $(11.2)>$ As $(2.55)>\mathrm{Cd}(0.77)>\mathrm{Mo}(0.37)>\mathrm{Cr}(0.35)>\mathrm{Ni}$ $(0.33)>\mathrm{Se}(0.07)>\mathrm{Hg}(0.001)$. In the COW-M and TREE-L NBM composts, they had the following order $\left(\mathrm{mg} \cdot \mathrm{kg}^{-1}\right): \mathrm{Zn}$ $(118.9)>\mathrm{Pb} \quad(27.21)>\mathrm{Cu} \quad(16.15)>\mathrm{As} \quad(2.57)>\mathrm{Cd} \quad(0.83)$ $>$ Mo $(0.41)>\mathrm{Ni}(0.37)>\mathrm{Cr}(0.32)>\mathrm{Se}(0.07)>\mathrm{Hg}(0.001)$. Figure 8 shows the evolution of the average values of the heavy metals and trace elements of interest extracted with
DTPA during the composting process in IBM and NBM piles and physicochemical variables $\left(\mathrm{pH}, \mathrm{T}^{\circ}, \mathrm{C} / \mathrm{N}\right.$ ratio, and $\mathrm{HA}$ ). The sums of the means of the ten elements of interest on day 0 for IBM and NBM $\left(\mathrm{mg} \cdot \mathrm{kg}^{-1}\right)$ were $119.69 \pm 7.50$ and $123.13 \pm 8.14$, and on day 120 , they presented values of $131.76 \pm 7.00$ and $166.90 \pm 12.95$, respectively. There was an average increase of $10.09 \%$ and $35.55 \%$ for IBM and NBM, respectively.

During composting, comparing the concentrations at day 0 and day 120 in both IBM and NBM piles, five of the elements had an increasing trend and the other five had a 


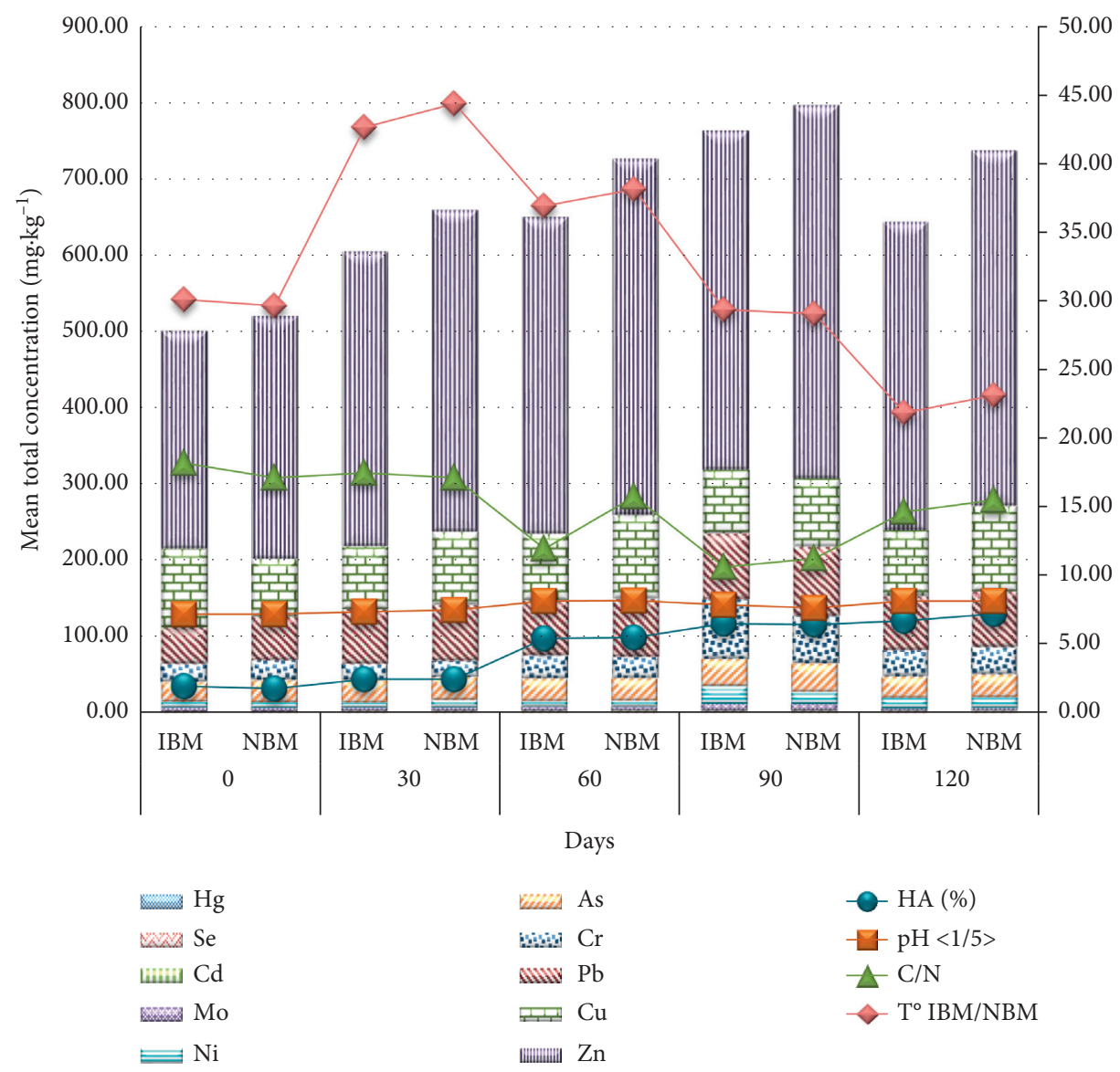

Figure 7: Total concentration of heavy metals and trace elements of interest and physicochemical variables (HA, $\mathrm{pH}, \mathrm{C} / \mathrm{N}$ ratio, and $\mathrm{T}^{\circ}$ ratios) during the composting of cattle manure and tree litter in piles inoculated with beneficial microorganisms (IBM) and in noninoculated (NBM) piles.

decreasing trend. The increases in the IBM piles had the following order: $\mathrm{Mo}(353.7 \%)>\mathrm{Cu}(62.7 \%)>\mathrm{Cd}(13.2 \%)$ $>\mathrm{Zn}(9.9 \%)>\mathrm{Pb}(0.8 \%)$. The reductions in the IBM piles had the following order: $\mathrm{Hg}(83.3 \%)>\mathrm{Ni}(68.0 \%)>\mathrm{Se}(45.7 \%)$ $>\mathrm{Cr}(32.7 \%)>$ As $(5.9 \%)$. The increases in the NBM piles had the following order: Mo $(182.1 \%)>\mathrm{Cu}(162.2 \%)>\mathrm{Zn}$ $(39.7 \%)>\mathrm{Cd}(13.5 \%)>\mathrm{Pb}(1.0 \%)$. The reductions in the NBM piles had the following order: $\mathrm{Hg}(85.7 \%)>\mathrm{Cr}$ $(43.9 \%)>\mathrm{Se}(42.6 \%)>\mathrm{Ni}(38.3 \%)>$ As $(4.8 \%)$. Statistical significance $(p<0.05)$ was observed in the increase in $\mathrm{Cu}$ and $\mathrm{Mo}$ and in the reduction of $\mathrm{Cr}, \mathrm{Ni}$, and Se for both pile types. In the variations, there is no trend indicating any influence of the inoculation with BM. Ciavatta et al. [40] observed in 60-day compost increases in the concentration of $\mathrm{Cu}, \mathrm{Pb}, \mathrm{Ni}$, and $\mathrm{Cd}$, but for $\mathrm{Zn}$ and $\mathrm{Cr}$, it remained almost constant. The opposite was found by Huang et al. [21] as they showed a 63-day composting reduction in $\mathrm{Cu}$ and $\mathrm{Zn}$ extracted with DTPA. The results are dissimilar to what was mentioned by the authors and the investigation. However, they do agree in the case of $\mathrm{Cu}$ and that mentioned by Ciavatta et al. [40].

The mean values of concentration of heavy metals and trace elements of interest extracted with deionized water from the COW-M and TREE-L IBM composts (Day 120) had the following order $\left(\mathrm{mg} \cdot \mathrm{kg}^{-1}\right)$ : As $(3.08)>\mathrm{Zn}(1.69)$ $>\mathrm{Mo}(0.71)>\mathrm{Cu}(0.62)>\mathrm{Pb}(0.44)>\mathrm{Ni}(0.26)>\mathrm{Cr}(0.21)$ $>\mathrm{Se}(0.09)>\mathrm{Cd}(0.007)>\mathrm{Hg}(0.002)$. In the COW-M and the TREE-L NBM composts, they had the following order $\left(\mathrm{mg} \cdot \mathrm{kg}^{-1}\right)$ : As $(3.14)>\mathrm{Zn}(1.85)>\mathrm{Mo}(0.74)>\mathrm{Cu}(0.7)>\mathrm{Pb}$ $(0.36)>\mathrm{Ni} \quad(0.29)>\mathrm{Cr} \quad(0.2)>\mathrm{Se} \quad(0.09)>\mathrm{Cd} \quad(0.007)>\mathrm{Hg}$ (0.002). Figure 9 shows the evolution of the average values of the heavy metals and trace elements of interest extracted with deionized water during the composting process in IBM and NBM piles and physicochemical variables $\left(\mathrm{pH}, \mathrm{T}^{\circ}, \mathrm{C} / \mathrm{N}\right.$ ratio, and $\mathrm{HA}$ ). The sums of the means of the ten elements of interest on day 0 for IBM and NBM $\left(\mathrm{mg} \cdot \mathrm{kg}^{-1}\right)$ were $13.09 \pm 2.53$ and $11.64 \pm 1.94$, and on day 120 , they presented values of $7.10 \pm 0.62$ and $7.38 \pm 0.44$, respectively. This meant an average reduction of $45.74 \%$ and $36.57 \%$ for IBM and NBM, respectively.

During the composting of COW-M and TREE-L, there was a decreasing trend in most of the concentrations of the analyzed elements extracted with deionized water, except Mo which showed an increasing trend comparing the values of day 0 and 120 . The reductions in the IBM piles had the following order: $\mathrm{Cu}(76.3 \%)>\mathrm{Hg}(75.0 \%)>\mathrm{Cd}(68.2 \%)>\mathrm{Ni}$ $(66.4 \%)>\mathrm{Zn}(64.5 \%)>\mathrm{Pb}(63.8 \%)>\mathrm{Cr}(41.7 \%)>\mathrm{Se}(28 \%)$ $>$ As (5.2\%). Mo increased by $46.6 \%$. The reductions in the 


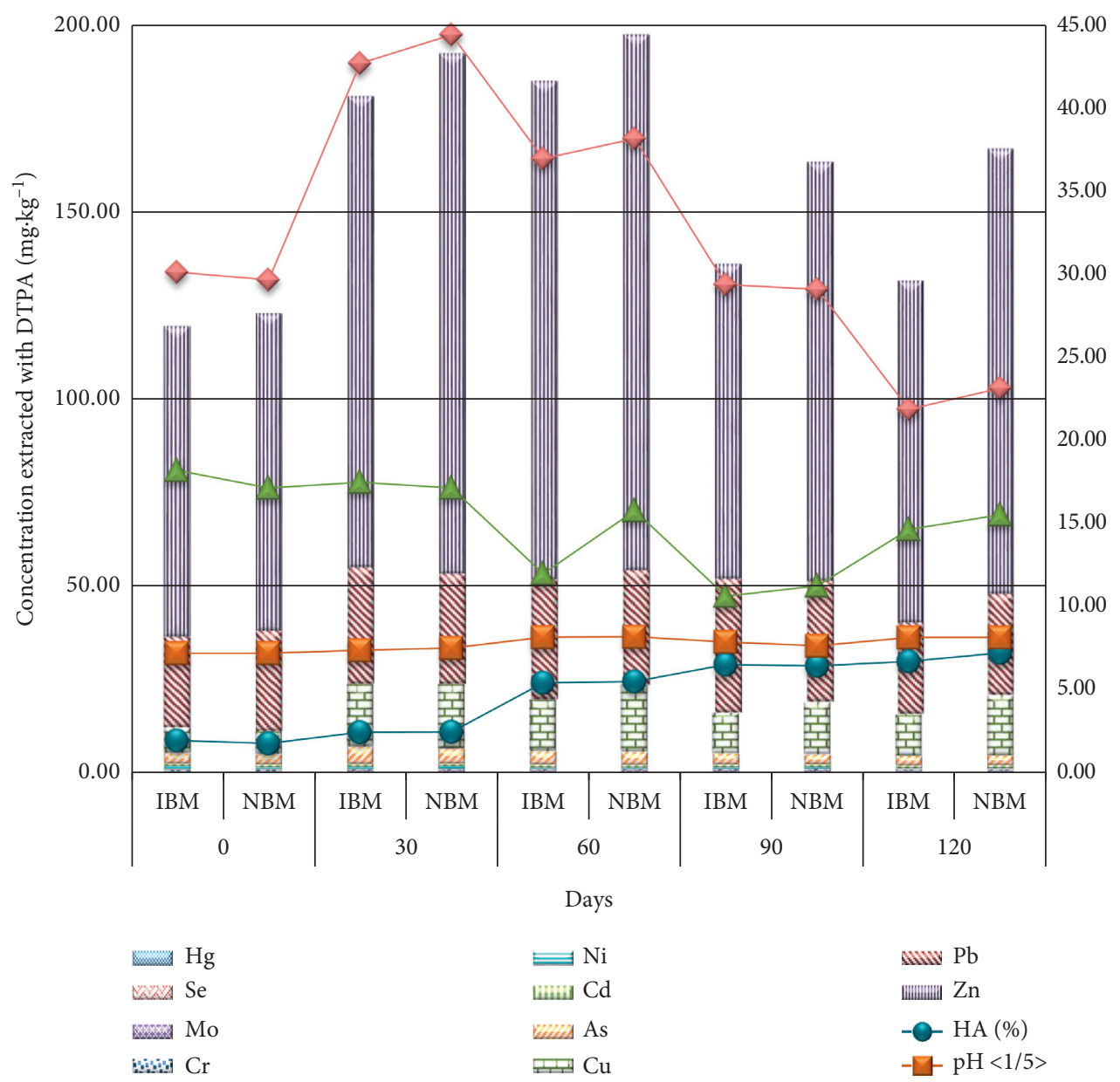

FIGURE 8: Concentration of heavy metals and trace elements of interest extracted with DTPA and physicochemical variables (HA, pH, temperature, and $\mathrm{C} / \mathrm{N}$ ratio) during the composting of cow manure and tree litter in piles inoculated with beneficial microorganisms (IBMs) and in noninoculated (NBM) piles.

NBM piles had the following order: $\mathrm{Cu}(68.9 \%)>\mathrm{Hg} 60.0 \%)$ $>\mathrm{Ni}(55.0 \%)>\mathrm{Cd}(53.3 \%)>\mathrm{Zn}(52.9 \%)>\mathrm{Pb}(47.9 \%)>\mathrm{Se}$ $(36.6 \%)>\operatorname{Cr}(25.9 \%)>$ As $(5.7 \%)$. Mo increased by $42.0 \%$. These results indicate that the composting process reduced the solubility and leaching of the metals other than Mo. Statistical significance $(p<0.05)$ was observed in the reduction in $\mathrm{Cu}, \mathrm{Ni}, \mathrm{Pb}$, and $\mathrm{Zn}$ for both types of piles, from which it can also be stated, without statistical significance, that in absolute terms, there are higher solubility reduction values for these elements in IBM piles than in NBM piles. Ciavatta et al. [40], Huang et al. [21], Castaldi et al. [37], Hargreave et al. [41], and Ramdani et al. [89] showed a reduction in the concentration of $\mathrm{Cd}, \mathrm{Cr}, \mathrm{Cu}, \mathrm{Ni}, \mathrm{Pb}$, and $\mathrm{Zn}$ extracted with deionized water in composting between 60 and 100 days, which resembles the results found in the present investigation.

\subsubsection{Statistical Analysis of the Primary and Secondary Variables of the Evaluation Stage}

(1) Analysis of the Primary Variables. $\mathrm{Zn}, \mathrm{Cu}$, and $\mathrm{Pb}$ are the three elements with the highest total concentration, and they also exceeded the maximum values for organic agriculture $[84,85]$. The $\mathrm{Cu}$ showed a significant difference, in both types of piles (IBM and NMB), between day 0 and 120 in the concentration extracted with DTPA and deonized water. For $\mathrm{Pb}$, the difference was shown in the extraction with deionized water. For $\mathrm{Zn}$, there were differences in total concentration and in extraction with deionized water (Figure 10).

3.3. Correlation of Variables. On the basis of those variables that were significant ( $p$ value $>0.05)$ in the Pearson correlation with a coefficient value greater than 0.5 and did not show any difference between the factors (inoculation and noninoculation), it was observed for the elements $\mathrm{Cu}, \mathrm{Ni}$, $\mathrm{Zn}, \mathrm{Cd}, \mathrm{Pb}, \mathrm{Se}$, and $\mathrm{Hg}$ extracted with water that they have a significant negative correlation with the humic acid fraction (Table 7). The same happens with $\mathrm{Se}, \mathrm{Ni}$, and $\mathrm{Hg}$ extracted 


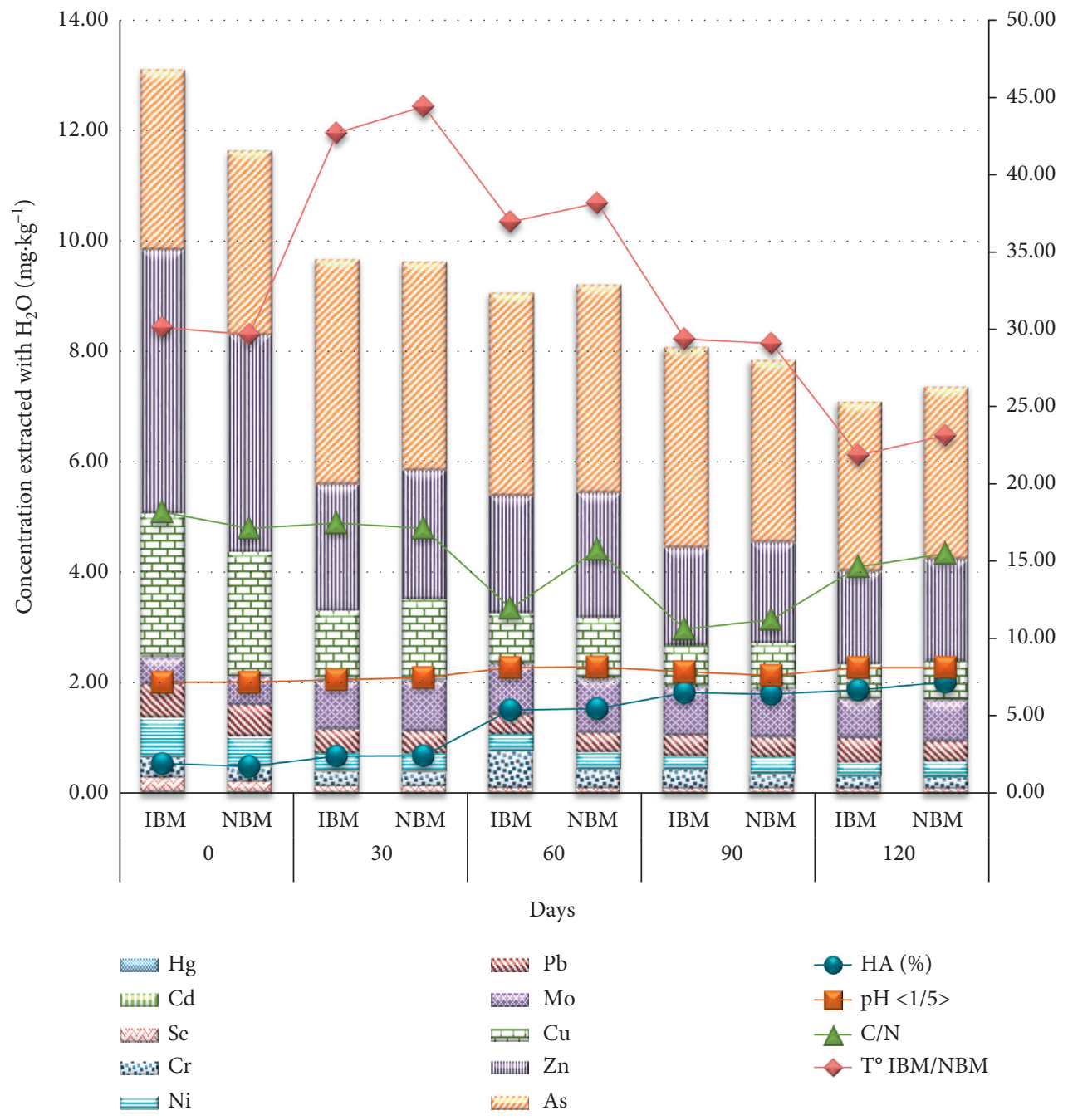

FIGURE 9: Concentration of heavy metals and trace elements of interest extracted with deionized water and physicochemical variables (HA, $\mathrm{pH}, \mathrm{C} / \mathrm{N}$ ratio, and $\mathrm{T}^{\circ}$ ) during the composting of cow manure and tree litter in piles inoculated with beneficial microorganisms (IBM) and in noninoculated (NBM) piles.

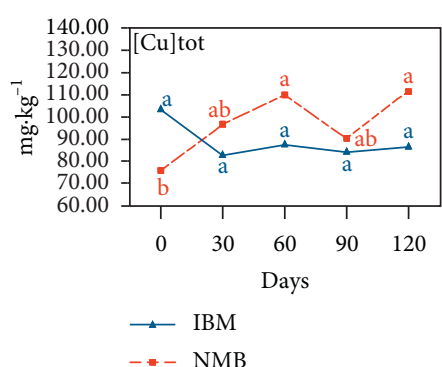

(a)
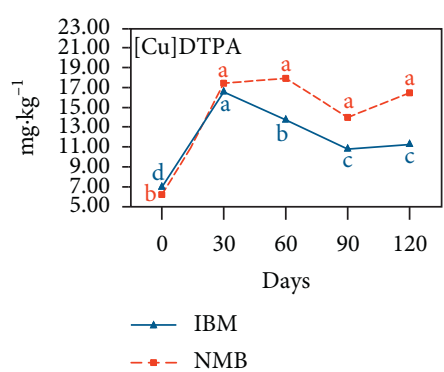

(d)

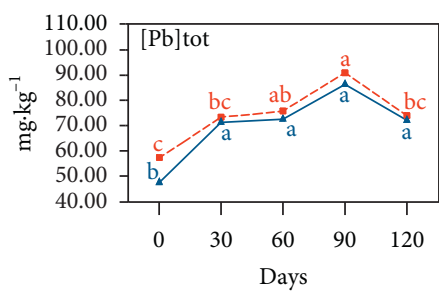

$\rightarrow$ IBM

$--\mathrm{NMB}$

(b)

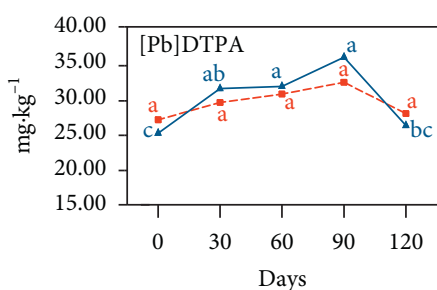

$\rightarrow$ IBM

(e)

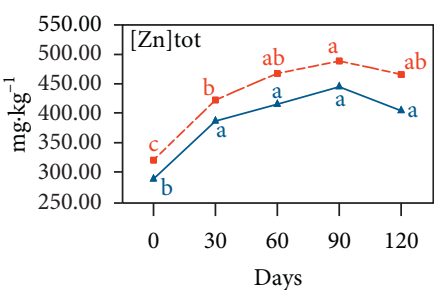

$\rightarrow$ IBM

- - NMB

(c)

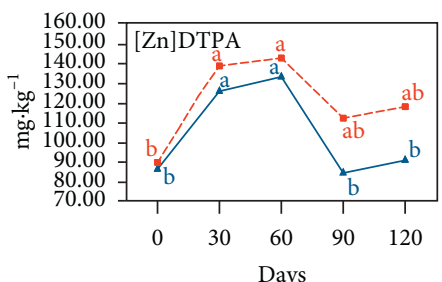

$\rightarrow$ IBM

-- NMB

(f)

Figure 10: Continued. 


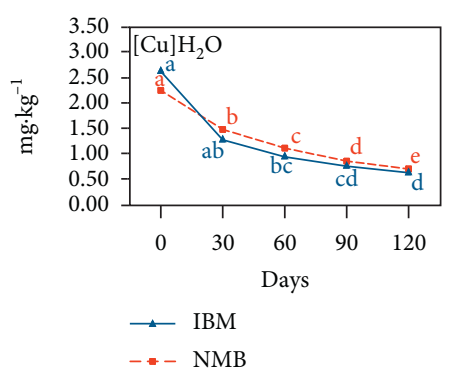

(g)

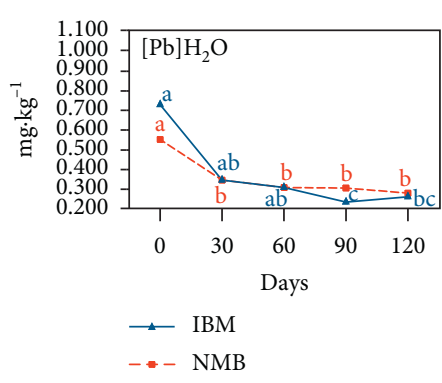

(h)

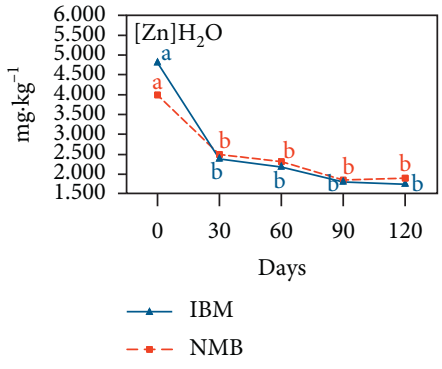

(i)

FIgURE 10: Total concentrations, extracted with DTPA and extracted with deionized water, of $\mathrm{Cu}, \mathrm{Pb}$, and $\mathrm{Zn}$ during the composting of cattle manure and tree litter in IBM and NMB piles. Between points on the lines with different letters the differences are statistically significant $(p<0.05)$.

TABle 7: Negative values of Pearson's correlation between primary variables and the AH, with significance without influence of the inoculation factor.

\begin{tabular}{lcccc}
\hline Primary variable $\left(\mathrm{mg}^{\left.-\mathrm{kg}^{-1}\right)}\right.$ & Secondary physicochemical variable $(\%)$ & $n$ & Pearson & $p$ value \\
\hline$[\mathrm{Cu}]_{\mathrm{H} 2 \mathrm{O}}$ & $\mathrm{HA}$ & 30 & -0.8410 & $5.94 \times 10^{-9}$ \\
{$[\mathrm{Se}]_{\mathrm{DTPA}}$} & $\mathrm{HA}$ & 30 & -0.8382 & $7.45 \times 10^{-9}$ \\
{$[\mathrm{Ni}]_{\mathrm{DTPA}}$} & $\mathrm{HA}$ & 30 & -0.7680 & $7.26 \times 10^{-7}$ \\
{$[\mathrm{Ni}]_{\mathrm{H} 2 \mathrm{O}}$} & $\mathrm{HA}$ & 30 & -0.7550 & $1.43 \times 10^{-6}$ \\
{$[\mathrm{Zn}]_{\mathrm{H} 2 \mathrm{O}}$} & $\mathrm{HA}$ & 30 & -0.7377 & $3.29 \times 10^{-6}$ \\
{$[\mathrm{Cd}]_{\mathrm{H} 2 \mathrm{O}}$} & $\mathrm{HA}$ & 30 & -0.6705 & $5.04 \times 10^{-5}$ \\
{$[\mathrm{Hg}]_{\mathrm{DTPA}}$} & $\mathrm{HA}$ & 30 & -0.6615 & $6.88 \times 10^{-5}$ \\
{$[\mathrm{~Pb}]_{\mathrm{H} 2 \mathrm{O}}$} & $\mathrm{HA}$ & 30 & -0.6269 & $2.10 \times 10^{-4}$ \\
{$[\mathrm{Se}]_{\mathrm{H} 2 \mathrm{O}}$} & $\mathrm{HA}$ & 30 & -0.6266 & $2.12 \times 10^{-4}$ \\
{$[\mathrm{Hg}]_{\mathrm{H} 2 \mathrm{O}}$} & $\mathrm{HA}$ & 30 & -0.5201 & $3.22 \times 10^{-3}$ \\
\hline
\end{tabular}

$[\cdot]$ total concentration; $[\cdot]_{\mathrm{DTPA}}:$ concentration extracted with pentatetic acid; $[\cdot]_{\mathrm{H} 2 \mathrm{O}}$ : concentration extracted with deioized water; HA: fraction of humic acids.

TABle 8: Positive values of Pearson's correlation between primary variables and the AH with significance without influence of the inoculation factor.

\begin{tabular}{|c|c|c|c|c|}
\hline Primary variable $\left(\mathrm{mg} \cdot \mathrm{kg}^{-1}\right)$ & Secondary physicochemical variable (\%) & $N$ & Pearson & $p$ value \\
\hline$[\mathrm{Cd}]_{\text {tot }}$ & HA & 30 & 0.5176 & $3.40 \times 10^{-3}$ \\
\hline$[\mathrm{Cr}]_{\text {tot }}$ & HA & 30 & 0.5788 & $8.06 \times 10^{-4}$ \\
\hline$[\mathrm{Ni}]_{\text {tot }}$ & HA & 30 & 0.5864 & $6.61 \times 10^{-4}$ \\
\hline$[\mathrm{Mo}]_{\text {DTPA }}$ & HA & 30 & 0.6223 & $2.41 \times 10^{-4}$ \\
\hline$[\mathrm{Pb}]_{\text {tot }}$ & HA & 30 & 0.6254 & $2.19 \times 10^{-4}$ \\
\hline$[\mathrm{Hg}]_{\text {tot }}$ & HA & 30 & 0.6633 & $6.47 \times 10^{-5}$ \\
\hline$[\mathrm{Zn}]_{\text {tot }}$ & HA & 30 & 0.7385 & $3.18 \times 10^{-6}$ \\
\hline$[\mathrm{Se}]_{\text {tot }}$ & HA & 30 & 0.8024 & $9.65 \times 10^{-8}$ \\
\hline
\end{tabular}

$[\cdot]$ total concentration; $[\cdot]_{\mathrm{DTPA}}$ concentration extracted with pentatetic acid; $[\cdot]_{\mathrm{H} 2 \mathrm{O}}$ c concentration extracted with deionized water; HA: fraction of humic acids.

with pentatetic acid. The opposite occurs with Mo extracted with pentatetic acid which shows a positive correlation with $\mathrm{AH}$ and in the total concentration of $\mathrm{Cd}$, $\mathrm{Cr}, \mathrm{Ni}, \mathrm{Pb}, \mathrm{Hg}, \mathrm{Zn}$, and Se (Table 8). Castaldi et al. [37] found a correlation of $-0.95 ;-0.95 ;-0.92$, and -0.90 $(p<0.01)$, respectively between the $\mathrm{Pb}, \mathrm{Cd}, \mathrm{Zn}$, and $\mathrm{Cu}$ extracted with deionized water and the $\mathrm{AH}$ after 100 days of composting of solid municipal waste in Italy, values higher than those found in this investigation, but which confirm the affinity between these two variables for these elements.

3.3.1. Unrestricted Sorting Analysis with Examination of Principal Components. Figure 11 shows that the variables $\mathrm{Cl}$ $\mathrm{N}$ and $\mathrm{OM}(\%)$ were highly correlated, as well as $\mathrm{Da}\left(\mathrm{g} \cdot \mathrm{cm}^{-3}\right)$ with $[\mathrm{Cr}]_{\text {tot }}\left(\mathrm{mg} \cdot \mathrm{kg}^{-1}\right)$ and that those variables with a negative correlation were $[\mathrm{Zn}]_{\mathrm{DTPA}}(\mathrm{mg} \cdot \mathrm{kg})$ and FA (\%). In the majority 


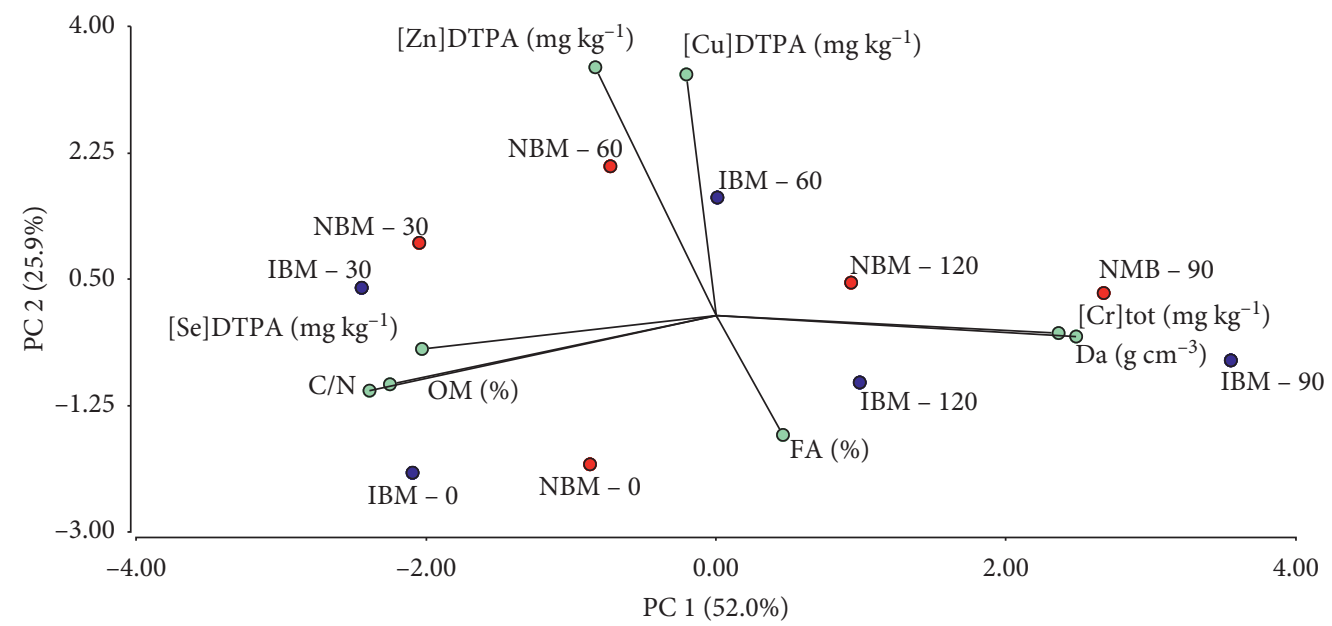

FIGURE 11: Unrestricted sorting analysis (with examination of principal components).

of cases, the effect of adding microorganisms was not observed to affect the results with respect to days (NBM and IBM). In most cases, the points are close. With respect to the treatment days, the difference between the grouping of the days 0 and 30, of day 60, and of the grouping 120 and 90 is remarkable. The variables $\mathrm{C} / \mathrm{N}, \mathrm{OM}(\%)$, and $[\mathrm{Se}]_{\text {DTPA }}\left(\mathrm{mg} \cdot \mathrm{kg}^{-1}\right)$ are more related to days 0 and 30 (especially IBM-30). The Da variables $\left(\mathrm{g} \cdot \mathrm{cm}^{-3}\right)$ with $[\mathrm{Cr}]_{\text {tot }}\left(\mathrm{mg} \cdot \mathrm{kg}^{-1}\right)$ are related to days 90 and 120 ; the $[\mathrm{Zn}]_{\text {DTPA }}$ variables $\left(\mathrm{mg} \cdot \mathrm{kg}^{-1}\right)$ and $[\mathrm{Cu}]_{\text {DTPA }}\left(\mathrm{mg} \cdot \mathrm{kg}^{-1}\right)$ are more related to day 60 .

\section{Discussions}

4.1. On the Variation of the Total Content, Bioavailability, and Solubility of the Heavy Metals and Trace Elements of Interest during the Composting of Cow Manure and Tree Litter. There is variation in total content between day 0 and 120 with a statistical significance $(p<0.05)$ in $\mathrm{Hg}, \mathrm{Mo}, \mathrm{Se}$, and $\mathrm{Zn}$ for both pile types (IBM and NBM). In $\mathbf{H g}$, with $34.5 \%$ increase (from 0.29 to $0.39 \mathrm{mg} \cdot \mathrm{kg}^{-1}$ ) for IBM and $35.7 \%$ increase (from 0.28 to $0.38 \mathrm{mg} \cdot \mathrm{kg}^{-1}$ ) for NBM. In Se, with $112.3 \%$ increase (from 0.65 to $1.38 \mathrm{mg} \cdot \mathrm{kg}^{-1}$ ) in IBM and $96.2 \%$ increase (from 0.79 to $1.55 \mathrm{mg} \cdot \mathrm{kg}^{-1}$ ) in NBM, and, in Zn, with $41.5 \%$ increase (from 285.67 to $404.33 \mathrm{mg} \cdot \mathrm{kg}^{-1}$ ) in IBM and $46.2 \%$ increase (from 318.67 to $466.0 \mathrm{mg} \cdot \mathrm{kg}^{-1}$ ) in NBM. In Mo, $43.7 \%$ reduction (de 5.08 a $2.86 \mathrm{mg} \cdot \mathrm{kg}^{-1}$ ) was observed in IBM and $32.6 \%$ reduction (from 4.79 to $3.23 \mathrm{mg} \cdot \mathrm{kg}^{-1}$ ) in NBM.

There is variation in bioavailability between day 0 and 120 with a statistical significance $(p<0.05)$ in $\mathrm{Cu}, \mathrm{Cr}, \mathrm{Mo}$, $\mathrm{Ni}$, and Se for both pile types (IBM and NBM) in $\mathbf{C u}$, with $62.7 \%$ increase (from 6.89 to $11.21 \mathrm{mg} \cdot \mathrm{kg}^{-1}$ ) in IBM and $162.2 \%$ increase (from 6.16 to $16.15 \mathrm{mg} \cdot \mathrm{kg}^{-1}$ ) in NBM.; in Mo, with $353.7 \%$ increase (from 0.082 to $0.372 \mathrm{mg} \cdot \mathrm{kg}^{-1}$ ) in IBM and $182.1 \%$ increase (from 0.145 to $0.409 \mathrm{mg} \cdot \mathrm{kg}^{-1}$ ) in NBM; in Cr, with $32.7 \%$ reduction (from 0.52 to $0.35 \mathrm{mg} \cdot \mathrm{kg}^{-1}$ ) for IBM and $43.9 \%$ reduction (from 0.57 to $0.32 \mathrm{mg} \cdot \mathrm{kg}^{-1}$ ) in NBM; in $\mathrm{Ni}$, with $68.0 \%$ reduction (from 1.03 to $0.33 \mathrm{mg} \cdot \mathrm{kg}^{-1}$ ) in IBM and $38.3 \%$ reduction (from 0.60 to $0.37 \mathrm{mg} \cdot \mathrm{kg}^{-1}$ ) in NBM; in Se, with $45.7 \%$ reduction (from
0.13 to $0.07 \mathrm{mg} \cdot \mathrm{kg}^{-1}$ ) for IBM and $42.6 \%$ reduction (from 0.12 to $0.07 \mathrm{mg} \cdot \mathrm{kg}^{-1}$ ) in NBM.

There is variation in solubility between day 0 and 120 with a statistical significance $(p<0.05)$ in $\mathrm{Cu}, \mathrm{Ni}, \mathrm{Pb}$, and $\mathrm{Zn}$ for both pile types (IBM and NBM) in $\mathbf{C u}$, with $76.3 \%$ reduction (from 2.62 to $0.62 \mathrm{mg} \cdot \mathrm{kg}^{-1}$ ) in IBM and $68.9 \%$ reduction (from 2.25 to $0.70 \mathrm{mg} \cdot \mathrm{kg}^{-1}$ ) in NBM; in $\mathrm{Ni}$, with $66.4 \%$ reduction (from 0.268 to $0.09 \mathrm{mg} \cdot \mathrm{kg}^{-1}$ ) in IBM and $55.0 \%$ reduction (from $0.2 \mathrm{mg} \mathrm{kg}^{-1}$ to $0.09 \mathrm{mg} \cdot \mathrm{kg}^{-1}$ ) in $\mathrm{NBM}$; in $\mathbf{P b}$, with $63.8 \%$ reduction (from 0.719 to $0.26 \mathrm{mg} \cdot \mathrm{kg}^{-1}$ ) in IBM and $47.9 \%$ reduction (from 0.547 to $0.285 \mathrm{mg} \cdot \mathrm{kg}^{-1}$ ) in NBM; in $\mathbf{Z n}$, with $64.5 \%$ reduction (from 4.764 to $1.689 \mathrm{mg} \cdot \mathrm{kg}^{-1}$ ) in IBM and $52.9 \%$ reduction (from 3.933 to $1.852 \mathrm{mg} \cdot \mathrm{kg}^{-1}$ ) in NBM.

The increase in the total content of $\mathrm{Hg}$, Se, and $\mathrm{Zn}$ is due to the loss of mass resulting from mineralization and volatilization of carbon and nitrogen [24]. The reduction in the total Mo content may be due to mobility resulting from the increase in $\mathrm{pH}$ [1]. The increased bioavailability of $\mathrm{Cu}$ and Mo is linked to mineralization and chelation processes that in some cases increase availability [1] and also to higher $\mathrm{pH}$ (>5.5) which influences availability in Mo [3]. The composting process reduced the solubility and leaching of $\mathrm{Cu}$, $\mathrm{Ni}, \mathrm{Pb}$, and $\mathrm{Zn}$, and there were higher solubility reduction values in the inoculated piles than in the noninoculated piles. It is understood that the oxidation process and the formation of organometallic complexes influenced the reduction of the soluble content of the mentioned elements $[21,37,42,90,91]$.

4.2. On the Influence of Humic and Fulvic Acids on Total Concentration, Bioavailability, and Solubility of the Heavy Metals and Trace Elements of Interest during the Composting of Cow Manure and Tree Litter. There is a positive correlation between the humic acid fraction and the total concentration of Se, $\mathrm{Zn}, \mathrm{Hg}, \mathrm{Pb}, \mathrm{Ni}, \mathrm{Cr}$, and $\mathrm{Cd}$ in the following order: Se $(+0.80)>\mathrm{Zn}(+0.73)>\mathrm{Hg}(0.66)>\mathrm{Pb}(+0.63)>\mathrm{Ni}(+0.59)$ $>\mathrm{Cr}(+0.58)>\mathrm{Cd}(+0.52)$. From the records, it can be concluded that humic acids could support the retention in 
the compost matrix of the mentioned elements, which would reduce their mobility and increase their concentration (bioaugmentation) while the organic matter mineralizes $[3,24,92-94]$. This affinity is confirmed by comparing the results of variation between days 0 and 120 for IBM and NBM. It should be noted that the As, which had the smallest increase in total concentration $(<10 \%)$ for both piles, confirming the nonaffinity with the $\mathrm{AH}[1,3]$.

There is a negative correlation between the concentration of the humic acid fraction and the concentration extracted with pentatetic acid for $\mathrm{Se}, \mathrm{Ni}$, and $\mathrm{Hg}$ in the following order: $\mathrm{Se}$ $(-0.84)>\mathrm{Ni}(-0.77)>\mathrm{Hg}(-0.66)$. A chelating or sequestering effect in the megastructure of the humic acid fraction can be understood, which generated a phenomenon of "immobility" in the compost matrix [90]. This is confirmed by the analysis of the variation between days 0 and 120 for inoculated and noninoculated piles because these three elements present the greatest reductions in their extracted concentrations. It is highlighted that the As, which had the lowest reduction extracted with pentatetic acid $(<6 \%)$ for both piles, confirming the nonaffinity with the $\mathrm{AH}[1,3]$.

There is a positive correlation $(+0.62)$ between the concentration of the humic acid fraction and the concentration of Mo extracted with pentatetic acid. This can infer a possible affinity in the disposition of this element for plants in the presence of humic acids $[3,88]$. This is confirmed by the analysis of the variation between days 0 and 120 for inoculated and noninoculated piles because this element presents the greatest increase of its extracted concentration.

There is a negative correlation between the concentration of the humic acid fraction and the concentration from the extraction with deionized water of $\mathrm{Cu}, \mathrm{Ni}, \mathrm{Zn}, \mathrm{Cd}, \mathrm{Pb}, \mathrm{Se}$, and $\mathrm{Hg}$ in the following order: $\mathrm{Cu}(-0.84)>\mathrm{Ni}(-0.76)>\mathrm{Zn}$ $(-0.74)>\mathrm{Cd}(-0.67)>\mathrm{Pb}(-0.63)>\mathrm{Se}(-0.63)>\mathrm{Hg}(-0.52)$. It is possible that the increased concentration of the humic acid fraction during the composting process influenced the reduction of the solubility of these elements, which infers a redistribution of the water-soluble fractions to more stable forms strongly bound to the humic acid fractions $[12,37,90]$. This is confirmed by the analysis of the variation between days 0 and 120 for IBM and NBM, due to the fact that these elements present the greatest reductions of their extracted concentrations. It should be noted that the As, which had the smallest reduction in the concentration extracted with deionized water $(<6 \%)$ for both piles, confirms the nonaffinity with the HA $[1,3]$.

The concentration of the fulvic acid fraction showed no significant correlation with any of the analyzed primary variables. Humic and fulvic acids are organic substances that can have a high capacity for generating bonds with heavy metals, due to the large number of functional groups. In this investigation, this was only indicated with humic acid for some heavy metals, which may be due to the raw materials and the types of extractants which were used [21, 95].

4.3. On the Influence of Inoculation with Beneficial Microorganisms on Total Concentration, Bioavailability, and Solubility of the Heavy Metals and Trace Elements of Interest.
Comparing day 0 (T0) and day 120 (T120), the total $\mathrm{Cu}$ content was reduced by $16.45 \%$ (from 103.33 to $86.33 \mathrm{mg} \cdot \mathrm{kg}^{-1}$ ) in IBM and increased by $48.32 \%$ (from 75.67 to $112.23 \mathrm{mg}$ on the influence of inoculation with beneficial microorganisms on total concentration, bioavailability, and solubility of the heavy metals and trace elements of interest $\mathrm{kg}^{-1}$ ) in NBM. Comparing the concentration in the final product (T120) of IBM and NBM, it was observed that the former registered $23.08 \%$ less concentration of total $\mathrm{Cu}$. Based on what has been recorded, it can be concluded that the inoculation of beneficial microorganisms reduced the total $\mathrm{Cu}$ concentration.

Comparing day 0 (T0) and day 120 (T120), the bioavailability of $\mathrm{Cu}$ increased $62.7 \%$ (from 6.89 to $11.21 \mathrm{mg} \cdot \mathrm{kg}^{-1}$ ) in IBM and $162.2 \%$ (from 6.16 to $16.15 \mathrm{mg} \cdot \mathrm{kg}^{-1}$ ) in NBM. Comparing the bioavailability of the $\mathrm{Cu}$ extracted in the final product (T120), we have $30.6 \%$ less concentration in IBM. From the above, it is concluded that the inoculation of the beneficial microorganisms reduced the bioavailability of $\mathrm{Cu}$.

Comparing day 0 (T0) and day 120 (T120), the bioavailability of $\mathrm{Zn}$ increased by $9.94 \%$ (from 83.32 to $91.60 \mathrm{mg} \cdot \mathrm{kg}^{-1}$ ) in IBM and by $39.71 \%$ (from 85.14 to $118.95 \mathrm{mg} \cdot \mathrm{kg}^{-1}$ ) in NBM. Comparing the bioavailable concentration of $\mathrm{Zn}$ in the final product (T120), we have $23 \%$ less in IBM. From the above, it is concluded that the inoculation of the beneficial microorganisms reduced the bioavailability of $\mathrm{Zn}$.

The inoculation of beneficial microorganisms did not influence, with statistical significance $(p<0.05)$, the extraction with deionized water of the heavy metals and trace elements of interest or the solubility of these elements.

The lower bioavailability of $\mathrm{Cu}$ and $\mathrm{Zn}$ in inoculated piles than in noninoculated piles may be due to the fact that inoculation increased the bioaugmentation of these elements in the cells of microorganisms, or the chelation with organic functional groups, or the sequestration in dead cells [45]. While the reduction in the concentration of the total $\mathrm{Cu}$ content remains unknown because of its low probability of volatilization, one possibility is that refractory compounds are generated that prevent its quantification [3].

\section{Conclusions}

The composting product made with tree litter and cattle manure from an urban area cannot be used in organic agriculture because $\mathrm{As}, \mathrm{Cd}, \mathrm{Cu}, \mathrm{Pb}$, and $\mathrm{Zn}$ do not comply with the maximum allowable values of Brazil and Austria. However, it is possible to use it in land rehabilitation and landscaping considering the Austrian standard and also in nonorganic agriculture in Peru. The presence of $\mathrm{Cu}$ and $\mathrm{Zn}$ in the composting product is due to the type of cattle feed and to atmospheric contamination, while for $\mathrm{As}, \mathrm{Cd}$, and $\mathrm{Pb}$, it is mainly due to the atmospheric contamination. Inoculation of beneficial microorganisms reduces the bioavailability of $\mathrm{Cu}$ and $\mathrm{Zn}$ in comparison with the compost from piles which were not inoculated. The composting process reduced in both pile types (IBM and NBM) and the solubility of $\mathrm{Cu}, \mathrm{Pb}$ and $\mathrm{Zn}$. Fulvic acids did not show a significant 
correlation with any of the elements; however, humic acids did show affinity with $\mathrm{Cd}, \mathrm{Cu}, \mathrm{Pb}$, and $\mathrm{Zn}$ but not with As. This affinity confirms that the soils of green spaces can be sinks for heavy metals. Likewise, we can infer that the compost of the cattle manure can be recommended as an amendment to soils to reduce the leaching of $\mathrm{Cu}$ and $\mathrm{Zn}$.

The responses of the ten elements under analysis are different, as we have observed. It is therefore unlikely that their bioavailability and solubility can be reduced with a single treatment technique. Specifically, in the case of As, its behavior associated with an increase in $\mathrm{pH}$ must be taken into account, for which other techniques such as the aggregation of biochar, zeolites, or vermicomposting could be considered. Regarding the presence of helminth oocysts, consideration should be given to increasing the frequency of turning and to inoculation with a greater activated stock solution of beneficial microorganisms in order to reach temperatures between 60 and $70^{\circ} \mathrm{C}$ and so eliminate them.

\section{Data Availability}

The data used to support the findings of this study are available from the corresponding author upon request.

\section{Conflicts of Interest}

The authors declare that there are no conflicts of interest.

\section{Acknowledgments}

This work was supported by the personnel and logistics of Domus Consultoria Ambiental SAC, experimental site, raw materials, and meterorological data of Universidad Nacional Agraria La Molina.

\section{Supplementary Materials}

Figure a: triplicate samples of the activated stock solution (ASS) of beneficial microorganisms at day 0. Figure b: collection of samples from the compost piles on day 120 (T120) of the evaluation stage. Table a: treatments investigated at the evaluation stage. (Supplementary Materials)

\section{References}

[1] B. Alloway, "Introduction," in Heavy Metals in Soilsp. 339, First edition, Blackie Academic \& Professional, Glassgow, UK, 1990.

[2] B. De Jesus and O. Yllano, "Bioaccumulation and bioconcentration of $\mathrm{Pb}$ in the tissues of Zea mays L." Philippine Journal of Science, vol. 134, no. 1, pp. 21-29, 2005.

[3] B. Alloway, Introduction in Heavy Metals in Soils Trace Metals and Metalloids in Soils and their Bioavailabilityp. 613, Third edition, Springer, Berlin, Germnay, 2013.

[4] A. Ferrer, "Intoxicación por metales," Anales Sis San Navarra, vol. 26, no. 1, pp. 141-153, 2003.

[5] D. Fontana, V. Lascano, N. Solá, S. Martinez, M. Virgolini, and M. Mazzieri, "Intoxicación por plomo y su tratamiento farmacológico," Revista de Salud Pública, vol. 17, no. 1, pp. 49-59, 2013.
[6] E. Abou, M. Hassan, I. Hassan, and B. Weheda, "Heavy metal content in leaves of Ficus retusa collected from ontaminated and uncontaminated sites in northern Egypt: mitigation of toxicity by washing treatments," Universal Journal of Environmental Research and Technology, vol. 1, no. 4, pp. 408-415, 2011.

[7] E. Hou, H. Xiang, J. Li, and D. Wen, "Heavy metal contamination in soils of remnant natural and plantation forests in an urbanized region of the pearl river delta, China," Forests, vol. 5, no. 5, pp. 885-900, 2014.

[8] M. B. Mcbride, H. A. Shayler, H. M. Spliethoff et al., "Concentrations of lead, cadmium and barium in urban gardengrown vegetables: the impact of soil variables," Environmental Pollution, vol. 194, pp. 254-261, 2014.

[9] M. Shaheen, F. El-Nakglaway, F. Almehadi, and A. Al-Shareef, "Heavy metals contents in ziziphus tree leaves under the effect of different industrial activities," vol. 6, no. 1, pp. 110-115, 2014.

[10] J. Ganoulis, "Risk analysis of wastewater reuse in agriculture," International Journal of Recycling of Organic Waste in Agriculture, vol. 1, pp. 1-9, 2012.

[11] G. Merrington, L. Winder, R. Parkinson, and M. Redman, Agricultural Pollution: Environmental Problems and Practical Solutions, C Press, London, UK, 2002.

[12] L. Chimuka and T. E. Manungufala, Sources, Bioavailability and Fate of Heavy Metals and Organic Contaminants in Compost Manure, Global Science Books, London, UK, 2009.

[13] E. K. Koledzi, G. Baba, S. Tchegueni et al., "Fate of some heavy metals in the composting of the urban solid waste produced in Lome, Togo," Journal of Environmental Chemistry and Ecotoxicology, vol. 5, no. 7, pp. 196-201, 2013.

[14] OECD \& China Development Research Foundation, Trends in Urbanisation and Urban Policies in OECD Countries: What Lessons for China?, OECD Publishing, Paris, France, 2010.

[15] FAO, Growing Greener Cities in Latin America and the Caribbean: An FAO Report on Urban and Peri-Urban Agriculture in the Region, FAO, Rome, Italy, 2014.

[16] L. V. Antisari, F. Orsini, L. Marchetti, G. Vianello, and G. Gianquinto, "Heavy metal accumulation in vegetables grown in urban gardens," Agronomy for Sustainable Development, vol. 35, no. 3, pp. 1139-1147, 2015.

[17] J. Moreno and R. Moral, Compostaje, Ediciones Mundi Prensa, Madrid, Spain, 2011.

[18] F. Ayari, R. Chairi, and R. Kossai, "Sequential extraction of heavy metals during composting of urban waste," Chinese Journal of Geochemistry, vol. 27, no. 2, pp. 121-125, 2008.

[19] A. M. R. Rezig, E. A. Elhadi, and A. R. Mubarak, "Effect of incorporation of some wastes on a wheat-guar rotation system on soil physical and chemical properties," International Journal of Recycling of Organic Waste in Agriculture, vol. 1, no. 1, pp. 1-15, 2012.

[20] G. Gigliotti, D. Businelli, and P. L. Giusquiani, “Trace metals uptake and distribution in corn plants grown on a 6-year urban waste compost amended soil," Agriculture, Ecosystems \& Environment, vol. 58, no. 2, pp. 199-206, 1996.

[21] G. Huang, W. Wong, B. Nagar, Q. Wu, and F. Li, Bioavailability of Heavy Metals during Humification of Organic Matter in Pig Manure Compost, Ecoweb, Norte, Philippines, 2005.

[22] Q.-Y. Cai, C.-H. Mo, Q.-T. Wu, Q.-Y. Zeng, and A. Katsoyiannis, "Concentration and speciation of heavy metals in six different sewage sludge-composts," Journal of Hazardous Materials, vol. 147, no. 3, pp. 1063-1072, 2007.

[23] J. Hogarh, J. Fobil, and G. Ofosu-Budu, "Assessment of heavy metal contamination and macro-nutrient content of 
composts for environmental pollution control in Ghana," Global Journal of Environmental Research, vol. 2, no. 3, pp. 133-139, 2008.

[24] A. Hanc and J. Szakova, P. Ochecova, Differences in the mobility of $\mathrm{Cd}, \mathrm{Cu}, \mathrm{Pb}$ and $\mathrm{Zn}$ during composting of two types of household bio-waste collected in four seasons," Bioresource Technology, vol. 168, pp. 204-213, 2014.

[25] N. Naveed, A. Batool, F. Rehman, and U. Hameed, "Leaves of roadside plants as bioindicator of traffic related lead pollution during different seasons in Sargodha, Pakistan," African Journal of Environmental Science and Technology, vol. 4, no. 11, pp. 770-774, 2010.

[26] j. Akan, L. Inuwa, Z. Chellube, and B. Lawan, "Heavy metals in leaf, stem bark of neem tree (Azadirachta indica) and roadside dust in maiduguri metropolis, borno state, Nigeria," Environment and Pollution, vol. 2, no. 1, 2013.

[27] M. Daylam-Jafarabad and D. Azadfar, M. Arzanesh, The ability to filter heavy metals of lead, copper and zinc in some species of tree and shrub," International Journal of Advanced Biological and Biomedical Research (IJABBR), vol. 1, no. 1, pp. 53-60, 2013.

[28] Y. Dogan, M. C. Unver, I. Ugulu, M. Calis, and N. Durkan, "Heavy metal accumulation in the bark and leaves of Juglans regia planted in Artvin," Biotechnology \& Biotechnological Equipment, vol. 28, no. 4, pp. 643-649, 2014.

[29] K. S. Patel, R. Sharma, N. S. Dahariya et al., "Heavy metal contamination of tree leaves," American Journal of Analytical Chemistry, vol. 6, no. 8, pp. 687-693, 2015.

[30] C. Dadea, S. Casagrande, N. La Rocca, T. Mimmo, A. Russo, and S. Zerbe, "Heavy metal accumulation in urban soils and deciduous trees in the city of Bolzano, Italy," Landscape Research and Nature Cinservation, vol. 15, pp. 35-42, 2016.

[31] L. Tello, J. Jave, and J. Guerrero, “Análisis de cuantificación de plomo en suelos de parques recreacionales de la ciudad de Limaperú," Ecología Aplicada, vol. 17, no. 1, 2018.

[32] F. A. Nicholson, B. J. Chambers, J. R. Williams, and R. J. Unwin, "Heavy metal contents of livestock feeds and animal manures in England and Wales," Bioresource Technology, vol. 70, no. 1, pp. 23-31, 1999.

[33] M. Irshad, A. Malik, S. Shaukat, S. Mushtaq, and M. Ashraf, "Characterization of heavy metals in livestock manures," Polish Journal of Environmental Studies, vol. 22, no. 4, pp. 1257-1262, 2012.

[34] F. Zhang, Y. Li, M. Yang, and W. Li, "Content of heavy metals in animal feeds and manures from farms of different scales in northeast China," International Journal of Environmental Research and Public Health, vol. 9, no. 8, pp. 2658-2668, 2012.

[35] B. Hokayem and D. El Azzi, "Fate of copper and zinc in cattle manure," in Proceedings of the International Conference on Chemical, Environment \& Biological Sciences (CEBS 2014), pp. 17-18, Kuala Lumpur, Malaysia, September 2014

[36] N. Ntui, U. Hassan, and O. Ushie, "Determination of heavy metals concentration in cow dung of grazing cattle in bauchi urban area, Nigeria," International Journal of Modern Analytical an Separation Sciences, vol. 3, no. 1, pp. 13-19, 2014.

[37] P. Castaldi, L. Santona, and P. Melis, "Evolution of heavy metals mobility during municipal solid waste composting," Fresenius Environmental Bulletin, vol. 15, 2006.

[38] E. Companys, J. Puy, and J. Galceran, "Humic acid complexation to $\mathrm{Zn}$ and Cd determined with the new electroanalytical technique AGNES," Environmental Chemistry, vol. 4, no. 5, pp. 347-354, 2007.

[39] M.-M. He, G.-M. Tian, and X.-Q. Liang, "Phytotoxicity and speciation of copper, zinc and lead during the aerobic composting of sewage sludge," Journal of Hazardous Materials, vol. 163, no. 2, pp. 671-677, 2009.

[40] C. Ciavatta, M. Govi, and A. Simoni, P. Sequi, Evaluation of heavy metals during stabilization of organic matter compost produced with municipal solid wastes," Bioresource Technology, vol. 43, pp. I47-I53, 1993.

[41] J. Hargreaves, M. Adl, P. Warman, and P. Warman, "A review of the use of composted municipal solid waste in agriculture," Agriculture, Ecosystems \& Environment, vol. 123, no. 1-3, pp. 1-14, 2008.

[42] J. Singh and A. Kalamdhad, "Bioavailability and leachability of heavy metals during composting-a review," International Research Journal of Environment Sciences, vol. 2, no. 4, pp. 59-64, 2013.

[43] C. White, J. A. Sayer, and G. M. Gadd, "Microbial solubilization and immobilization of toxic metals: key biogeochemical processes for treatment of contamination," FEMS Microbiology Reviews, vol. 20, no. 3, pp. 503-516, 1997.

[44] X. Zeng, H. Xu, J. Lu et al., "The inmobilization of soil cadmium by the combined amedment of bactéria and hydroxyapatite," Scientific Reports, vol. 10, p. 2189, 2020.

[45] N. L. Singh, "Microorganisms in the conversion of agricultural wastes to compost," Proceedings of the Indian National Science Academy, vol. 80, no. 2, pp. 473-481, 2014.

[46] M. Vásquez de Díaz and M. M. Prada, "Optimización del proceso de compostaje de productos post-cosecha (cereza) del café con la aplicación de microorganismos nativos," Nova-Publicación Científica en Ciencias Biomédicas, vol. 8, no. 14 , pp. 121-240, 2010.

[47] L. Lim and L. C. Chua, "Composting and microbiological additive effects on composting," Environmental Science: An Indian Journal, vol. 8, no. 9, pp. 333-343, 2013.

[48] N. Delangiz, M. Varjovi, and G. M. Lajayer, "Beneficial microorganisms in the remediation of heavy metals," in Molecular Aspects of Plant Beneficial Microbies in Agriculture, pp. 417-421, Elsevier, Amsterdam, Netherlands, 2020.

[49] N. Premalatha, S. Sundaram, R. Krishnamoorthy et al., "Organic waste composting with bacterial consortium and its effect on plant growth promotion," Asian Journal of Plant Science and Research, vol. 8, no. 3, pp. 22-30, 2017.

[50] R. Cáceres and O. Marfa, "Compostaje estático versus compostaje dinámico en el tratamiento de estiércol de vacuno," in Proceedings of the II Jornadas de la Red Española de Compostaje, IV Reunión de la Red Española de Compostaje, pp. 446-456, Santiago de Compostela, Spain, 2010.

[51] M. Ahmed, A. Idris, and S. Syed Omer, "Physicochemical characterization of compost of the industrial tannery sludge," Journal of Engineering Science and Technology, vol. 2, no. 1, pp. 81-94, 2007.

[52] N. Soobhany, R. Mohee, and V. K. Garg, "Comparative assessment of heavy metals content during the composting and vermicomposting of municipal solid waste employing Eudrilus eugeniae," Waste Management, vol. 39, pp. 130-145, 2015.

[53] OISCA, "Manual práctico de uso de EM," Banco Interamericano de Desarrollo-Convenio Fondo Especial de Japón/ BID ATN/JO-10792 UR, OISCA, Tokyo, Japan, 2009.

[54] K. B. Reis, M. V. D. C. B. Côrtes, F. S. Martins, M. C. C. D. Filippi, J. R. D. Paula, and E. C. D. Conceição, "Characterization of rue extract and its potential for controlling rice blast," Pesquisa Agropecuária Brasileira, vol. 50, no. 12, pp. 1121-1130, 2015.

[55] D. Reddy and A. Al-Rajab, "Chemical composition, antibacterial and antifungal activities of Ruta graveolens L. volatile oils," Cogent Chemistry, vol. 2, no. 1, 2016. 
[56] M. Alvarez, Caracterización de microorganismos benéficos provenientes de tres pisos altitudinales de Azuay Ecuador y su influencia en el cultivo de fresa, Universidad Nacional Agraria La Molina, Lima, Peru, 2018.

[57] A. Pallag, G. Filip, D. Olteanu et al., "Equisetum arvense L. extract induces antibacterial activity and modulates oxidative stress, inflammation, and apoptosis in endothelial vascular cells exposed to hyperosmotic stress," Oxidative Medicine and Cellular Longevity, vol. 2018, p. 14, Article ID 3060525, 2018.

[58] N. F. Sumintarti, A. Hajrah-Yusuf, and M. Ruslin, "Effects of rosemary (Rosmarinus officinalis L.) leaf extract on angular cheilitis induced by staphylococcus aureus and candida albicans in male wistar rats," International Journal of Applied Pharmaceutics, vol. 10, no. 1, pp. 178-181, 2018.

[59] APROLAB, "Manual para la producción de compost con microorganismos eficaces," Programa de Apoyo a la Formación Profesional para la Inserción Laboral en el Perú Capacitate Perú-Convenio ALA, Vol. 21, APROLAB, Marseille, France, 2007.

[60] US Composting Council \& USDA, Test Methods for the Examination of Composting and Compost (TMECC), US Composting Council \& USDA, Washington, DC, USA, 2001.

[61] A. Walkley and I. A. Black, "An examination of the Degtjareff method for determining soil organic matter, and a proposed modification of the chromic acid titration method," Soil Science, vol. 37, no. 1, pp. 29-38, 1934.

[62] Association of Oficial Analytical Chemists Inc., Method AOAC 955.04 18th Ed: Nitrogen (Total) in Fertilizers, Kjeldahl Method, Richmond, VI, USA, 2005.

[63] A. Sadzawka, M. Carrasco, R. Grez, and M. Mora, Métodos de Análisis de COMPOST, Instituto de Investigaciones Agropecuarias, Santiago, Chile, 2005.

[64] F. Cabrera, C. Guevara, J. Castillo, and W. Chavarria, "Estandarización del método Kononova-Belchikova para la extracción, fraccionamiento, análisis y purificación de las sustancias húmicas en suelos andisoles," Revista de Ciencias Agrícolas, vol. 19, no. 1, pp. 131-139, 2002.

[65] H. Rodriguez, "Métodos de análisis de suelos y plantas: criterios de interpretación,” p. 288, 3 edition, Universidad Autónoma de Nuevo León, San Nicolás de los Garza, Mexico, 2015.

[66] International Commision on Microbiological Specifications for Food [ICMS], Microorganismos de los Alimentos 1: Su Significado y Métodos de Enumeración, Editorial Acribia, Zaragoza, Spain, 1983.

[67] American Public Health Association (APHA), Compendium of Methods for the Microbiological Examination of Foods, APHA, Washington, DC, USA, 1992.

[68] P. Moodley, C. Archer, and D. Hawksworth, Standards Methods for the Recovery and Enumeration of Helminth Ova in Wastewater, Sludge, Compost and Urine-Diversion Waste in South Africa: Report to the Water Research Commission (WRC), WRC Report No. TT322/08, Water Research Commission (WRC), Pretoria, South Africa, 2008.

[69] United States Environmental Protection Agency [EPA], Method EPA 3050B. Acid Digestion of Sediments, Sludges and Soils. Test Method for Evaluating Solid Waste Physical Chemical Methods (SW 846) Final Upadte IV, Washington DC, 2007.

[70] United States Environmental Protection Agency [EPA], Method EPA 6020A. Inductively Coupled Plasma-Mass Spectrometry: Test Method for Evaluating Solid Waste Physical Chemical Methods (SW 846) Final Update IV, United States
Environmental Protection Agency (EPA), Washington, DC, USA, 2007.

[71] D. Montgomery, Diseño y Análisis de Experimentos, Editorial Limusa, Leon, Mexico, 2 edition, 2014.

[72] J. Di Rienzo, R. Macchiavelli, and F. Casanoves, "Modelos lineales generalizados mixtos: aplicaciones en infostat, primera edición especial," 2017.

[73] S. S. Shapiro and R. S. Francia, "An approximate analysis of variance test for normality," Journal of the American Statistical Association, vol. 67, no. 337, pp. 215-216, 1972.

[74] Instituto Nacional de Normalización, Chile, Norma Chilena Oficial Nch 2880 of 2004, Instituto Nacional de Normalización, Santiago, Chile, 2004.

[75] J. O. Azeez and W. Van Averbeke, "Dynamics of soil ph and electrical conductivity with the application of three animal manures," Communications in Soil Science and Plant Analysis, vol. 43, no. 6, pp. 865-874, 2012.

[76] Y. Marmolejo, F. Perez, F. Prieto, and O. Acevedo, "Effect of the application of manure of cattle on the properties chemistry of soil in Tizayuca, Hidalgo, Mexico," International Journal of Applied Science and Technology, vol. 4, no. 3, pp. 67-72, 2014.

[77] E. Ozlu and S. Kumar, "Response of soil organic carbon, $\mathrm{pH}$, electrical conductivity, and water stable aggregates to longterm annual manure and inorganic fertilizer," Soil Science Society of America Journal, vol. 82, no. 5, pp. 1243-1251, 2018.

[78] H. Ch'ng, O. Ahmed y, and A. M. N. Kassim, "Co-composting of pineapple leaves and chicken manure slurry," International Journal of Recycling of Organic Waste in Agriculture, vol. 23, 2013.

[79] G. Reddy, S. Pranavi, B. Srimoukthika, and V. Reddy, "Isolation and characterization of bacteria from compost for municipal solid waste from Guntur and Vijayawada," Journal of Pharmaceutical Sciences and Research, vol. 9, no. 9, pp. 1490-1497, 2017.

[80] M. Ahmed, A. Idris, and S. Syed Omer, "Behaviour and fate of heavy metals in the composting of industrial tannery sludge," The Malaysian Journal of Analytical Sciences, vol. 11, no. 2, pp. 340-350, 2007.

[81] M. Haroun, A. Idris, and S. Omar, "Analysis of heavy metals during composting of the tannery sludge using physicochemical and spectroscopic techniques," Journal of Hazardous Materials, vol. 165, no. 1-3, pp. 111-119, 2009.

[82] INDECOPI, Norma Técnica Peruana. Fertilizantes. Productos Orgánicos Usados Como Abonos o Fertilizantes y Enmiendas o Acondicionadores de Suelos: NTP 311.577, INDECOPI, Lima, Peru, 1 edition, 2013.

[83] VIVIENDA, Decreto Supremo que Aprueba el Reglamento Para el Reaprovechamiento de Lodos Generados en las Plantas de Tratamiento de Aguas Residuales, VIVIENDA, Lima, Peru, 2017.

[84] I. Gomes, M. Baptista, and M. Gonçalves, "Legislation survey on composting operations and compost use \& methods for evaluation of process efficiency and compost quality in participating countries," 2004.

[85] MAPA, "Instrução normativa: reglamento técnico para os sistemas orgânicos de produção animal e vegetal," 2011.

[86] Y. Liu, L. Ma, Y. Li, and L. Zheng, "Evolution of heavy metal speciation during the aerobic composting process of sewage sludge," Chemosphere, vol. 67, no. 5, pp. 1025-1032, 2007.

[87] I. Villar, D. Pérez, J. Patiño, and M. S. Doínguez, Estudio de la Concentración de Metales Pesados en Distintas Fracciones Granulométricas Durante el Compostaje de Residuos Orgánicos Municipales, Burgos, Servicio de Publicaciones e 
Imagen Institucional de la Universidad de Burgos, Burgos, Spain, 2010.

[88] M. Bozym and A. Rajmund, "The study of molybdenum leaching from soils fertilized with sewage sludge and their composts," Chemik, vol. 68, no. 10, pp. 874-879, 2014.

[89] N. Ramdani and A. Lousdad, A. Hamous, Study of the biodegradation and fertility of the co-composting produced from sewage sludge and green waste and its effects on the speciation of heavy metals," Journal of Materials and Environmental Science, vol. 6, no. 5, pp. 1310-1320, 2015.

[90] W. R. Singh, S. K. Pankaj, and A. S. Kalamdhad, "Reduction of bioavailability and leachability of heavy metals during agitated pile composting of Salvinia natans weed of Loktak lake," International Journal of Recycling of Organic Waste in Agriculture, vol. 4, no. 2, pp. 143-156, 2015.

[91] K. Palansooriya, S. Shaheen, S. Chen et al., "Soil amendments for inmobilization of potentially toxic elements in contaminated soils: a critical review," Environment International, vol. 134, 2020.

[92] J. Porta, M. López-Acevedo, and C. Roquero, Edafología Para la Agricultura y el Medio Ambiente, Ediciones Mundi-Prensa, Barcelona, Spain, 3 edition, 2003.

[93] E. Tipping, Cation Binding by Humic Substances, Cambridge University Press, Cambridge, UK, 2004.

[94] G. Navarro and S. Navarro, Química Agrícola: Química del Suelo y de los Nutrientes Esenciales Para las Plantas, Ediciones Mundi-Prensa, Barcelona, Spain, 3 edition, 2013.

[95] M. Liu, Z. Tang, Z. Lin et al., "Insight into the cadmium and zinc binding potential of humic acids derived from composts by EEM spectra combined with PARAFAC analysis," Open Chemistry, vol. 18, no. 1, pp. 58-68, 2020. 